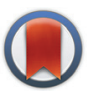

CrossMark $\leftarrow$ click for updates

Cite this: Org. Biomol. Chem., 2016, 14, 1599

Received 1st December 2015, Accepted 24th December 2015

DOI: $10.1039 / c 5 o b 02461 g$

www.rsc.org/obc

\title{
Design and synthesis of dihydroisoquinolones for fragment-based drug discovery (FBDD) $\uparrow$
}

\author{
Nick Palmer, Torren M. Peakman, David Norton and David C. Rees*
}

This study describes general synthesis aspects of fragments for FBDD, as illustrated by the dihydroisoquinolones 1-3. Previous Rh(III) methodology is extended to incorporate amines, heteroatoms ( $\mathrm{N}$ and $\mathrm{S}$ ), and substituents (halogen, ester) as potential binding groups and/or synthetic growth points for fragment-to-lead elaboration.

\section{Introduction}

\section{Fragment-based drug discovery}

FBDD is well-established within many Pharma, biotech and academic institutions as a technology for generating new chemical matter for drug discovery. ${ }^{1}$ Over 20 compounds derived from fragment-based drug discovery (FBDD) are being evaluated in clinical trials ${ }^{2}$ and the BRAF kinase inhibitor, vemurafenib (Zelboraf) is a launched drug for late stage melanoma. ${ }^{3}$

Organic chemistry is one of the enabling sciences required for FBDD and has been critical for the successful development of this field during the last decade. However, as FBDD has developed it has unearthed a pressing need to design and synthesise more fragments and to develop new synthetic methodology to convert fragments into leads. The successful prosecution of FBDD projects often requires new organic synthesis methodology which, not surprisingly, is frequently timecritical. This is increasingly an issue as more difficult protein drug discovery targets are screened. There are two areas in particular that need synthetic methodology research: (1) the design and synthesis of new fragments and (2) the elaboration of low affinity ( $\mu \mathrm{M}$ or $\mathrm{mM}$ ) fragments into high affinity (nM) leads using precisely controlled synthetic growth points (vectors).

Compared to drugs or high throughput screening (HTS) compounds, fragments are small, simple molecules. A key advantage of screening low MW fragments (in comparison with higher MW, HTS-like compounds) is the improved hit rate resulting from screening such small compounds. Fragments are designed to form efficient binding interactions with protein targets but, due to their small size, the typical binding

Astex Pharmaceuticals, 436 Cambridge Science Park, Milton Road, Cambridge CB4 oQA, UK. E-mail: david.rees@astx.com

$\dagger$ Electronic supplementary information (ESI) available. See DOI: 10.1039/ c5ob02461g affinity of a fragment is only $\mathrm{mM}$ or $\mu \mathrm{M}$. Table $1^{4}$ summarises guidelines indicating some of the chemical properties that we use today as part of the selection process for adding new fragments into the Astex screening library. These guidelines have evolved significantly compared to earlier descriptions of fragments as a result of 10 years of screening fragments by X-ray crystallography and other biophysical techniques. ${ }^{5}$ There are many other publications describing fragment library design ${ }^{6}$ and there are fragments with properties outside those listed in Table 1 that have been used to generate useful leads, so this is still an emerging area.

To grow fragments into leads requires the incorporation of additional binding groups to interact with the protein target.

Table 1 Aspirational properties of many Astex fragments

\begin{tabular}{|c|c|}
\hline Property & Guideline \\
\hline $\begin{array}{l}\text { Molecular } \\
\text { recognition }\end{array}$ & $\begin{array}{l}\text { Diverse, usually polar groups for binding to a } \\
\text { protein (a single pharmacophore). An } \\
\text { aspiration is to express any given binding } \\
\text { pharmacophore in a variety of chemotypes }\end{array}$ \\
\hline Synthetic vectors & $\begin{array}{l}\text { Multiple synthetically accessible positions for } \\
\text { fragment growth in } 3 \text { dimensions to form new } \\
\text { binding interactions }\end{array}$ \\
\hline \multirow{6}{*}{$\begin{array}{l}\text { Physico-chemical } \\
\text { properties }\end{array}$} & Molecular weight: $~ 140-230$ \\
\hline & Non-hydrogen atoms: $10-16$ \\
\hline & Lipophilicity $(\operatorname{clog} P): \sim 0.0$ to 2.0 \\
\hline & $\begin{array}{l}\text { Properties commensurate with biophysical } \\
\text { screening at high concentrations, e.g., aqueous }\end{array}$ \\
\hline & $\begin{array}{l}\text { solubility (preferably } \geq 5 \mathrm{mM} \text { in } 5 \% \text { DMSO, or } \\
\text { other screening co-solvents); stability ( }>24 \mathrm{~h} \text { in } \\
\text { solution); avoid compounds/functional groups }\end{array}$ \\
\hline & $\begin{array}{l}\text { known to be associated with high reactivity, } \\
\text { aggregation in solution, or false positives. }{ }^{7} \mathrm{NB} \text { : } \\
\text { aromatic } \mathrm{C}-\mathrm{H} \text { bonds may assist NMR screening }\end{array}$ \\
\hline Synthetic tractability & $\begin{array}{l}\text { Typically, } \sim 50-100 \mathrm{mg} \text { and } \leq 4 \text { steps from } \\
\text { commercially available reagents }\end{array}$ \\
\hline \multirow[t]{3}{*}{ Shape } & $\begin{array}{l}\text { Variety of 2- and 3-dimensional shapes for each } \\
\text { scaffold and pharmacophore }\end{array}$ \\
\hline & Number of freely rotatable bonds: $0-3$ \\
\hline & Number of chiral centres: $0-1$, sometimes 2 \\
\hline
\end{tabular}




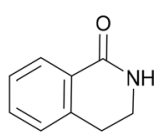

1

$\mathrm{MW}=147$

$\operatorname{cLog} P=1.0$

sol $\geq 5 \mathrm{mM}$

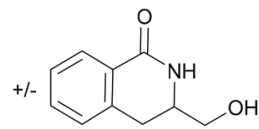

2

$\mathrm{MW}=177$

cLogP $=0.32$

sol $\geq 5 \mathrm{mM}$

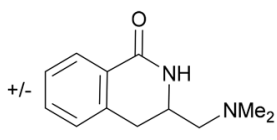

3

$\mathrm{MW}=204$

cLogP $=1.3$

sol $\geq 5 \mathrm{mM}$
Fig. 1 Dihydroisoquinolones with attractive fragment-like properties.

For this, it is desirable to rapidly elaborate the fragment in any direction with either polar or non-polar groups, ideally with regio- and stereo-control utilising synthetic methodology that has been worked out in advance. These requirements place big demands on synthetic methodology and represent an opportunity to significantly improve FBDD.

\section{Selection of dihydroisoquinolones as fragments}

Dihydroisoquinolone (1, Fig. 1) is a simple, small molecule $(\mathrm{MW}=147, \operatorname{clog} P=1.0)$ and contains a strong hydrogenbonding motif in the form of the cis-amide. Low complexity ${ }^{8}$ plus a polar binding motif are important factors to increase the probability of a fragment being a screening hit. The related fragments 2 and 3 are examples of compounds that could be made after $\mathbf{1}$ is identified as a fragment hit from a screening campaign. Furthermore, compounds 2 and $\mathbf{3}$ are attractive as fragments in their own right due to:

- low MW (177, 204 respectively) and $\operatorname{low} \operatorname{clog} P(0.32,1.3$ respectively)

- sufficient aqueous solubility ( $>5 \mathrm{mM}$ ) for screening

- polar H-bonding groups (amide + alcohol/amine)

- numerous positions available for synthetic elaboration (fragment-to-lead stage)

Thus, we selected the dihydroisoquinolones 2 and 3 as prototype examples to develop an FBDD-friendly synthetic methodology. The synthesis of fragment 2 has been reported previously using $\mathrm{Rh}(\mathrm{III})$ catalysed $\mathrm{C}-\mathrm{H}$ bond activation methodology (Fig. 2). ${ }^{9}$ This synthesis uses readily available starting materials; proceeds at room temperature with no requirement to exclude air; is amenable to $>100 \mathrm{mg}$ scale and frequently the two regioisomers ( $\mathrm{a}$ and $\mathrm{b}$ ) can be separated by chromatography. Whilst both of these regioisomers meet many of the guidelines in Table 1 we prefer fragments not to have distally separated polar binding groups hence we prefer isomer (a) for FBDD. The methodology in Fig. 2 utilises catalytic rhodium $\mathrm{C}-\mathrm{H}$ bond activation and has been developed in

$\$ \operatorname{cog} P$ is calculated from Daylight version 4.93 http://www.daylight.com/ products/toolkit.html.

Solubility measurements were carried out by ${ }^{1} \mathrm{H}$ quantitative NMR at $500 \mathrm{MHz}$ using the QUANTAS approach. ${ }^{19}$ Aliquots of fragments (100 mM in DMSO-d6) were diluted $\times 20$ with buffer $\left(40 \mathrm{mM}\right.$ phosphate, $100 \mathrm{mM}$ TRIS, $15 \% \mathrm{D}_{2} \mathrm{O}, \mathrm{pH}=$ 7.1) to afford samples with nominal concentrations of $5 \mathrm{mM}$. A $2.5 \mathrm{mM}$ sample of $p$-hydroxybenzoic acid, prepared by dilution of a $50 \mathrm{mM}$ stock in DMSO-d6 $\times 20$ with buffer was used as the qNMR standard.

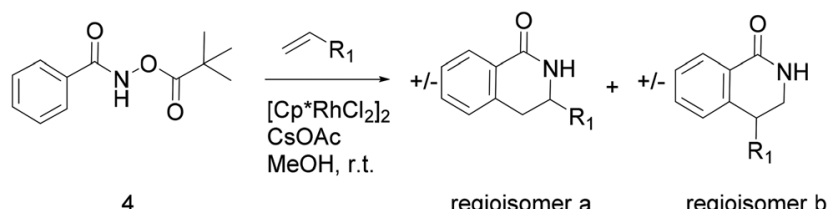

Fig. 2 Previously published synthesis of dihydroisoquinolones utilising Rh(III) catalytic C-H activation. ${ }^{9,10 c}$

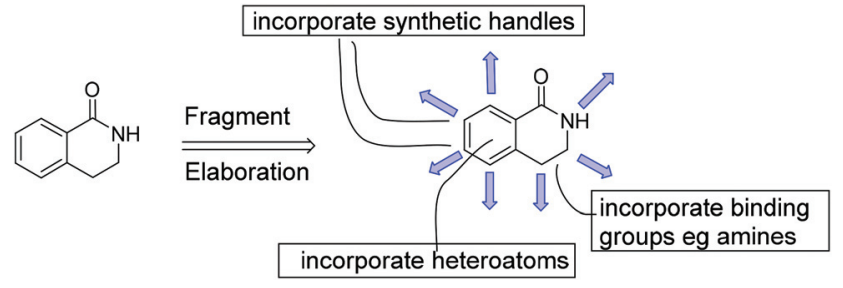

Fig. 3 Schematic representation of synthetic elaboration of fragment 1. Growth positions are shown as blue arrows and the incorporation of aromatic heteroatoms and polar binding groups are indicated.

several subsequent publications. ${ }^{10}$ The mechanism is thought to involve metal coordination to the nitrogen moiety which directs cyclometalation to the ortho $\mathrm{C}-\mathrm{H}$ bond. Alkene insertion occurs via coordination to the metal and the acyl protecting group acts as an internal oxidant. This methodology has also been reported with alkynes leading to isoquinolones and extended to substituted alkenes (for dihydroisoquinolones). ${ }^{9-11}$ The versatility of the methodology is further illustrated with other publications that describe, for related systems, chiral induction at the asymmetric carbon utilising an engineered metalloenzyme ${ }^{10 d, e, 12}$ or controlling the ratio of the two regioisomers by modulating the steric properties of the $\mathrm{Rh}(\mathrm{III})$ catalyst. $^{10 \mathrm{~b}}$

\section{Extending the dihydroisoquinolone methodology for FBDD}

Despite the modern synthetic methodology of Fig. 2 and the attractive fragment properties, we perceived some additional requirements from an FBDD perspective. Firstly, many drugs contain amino groups or heterocyclic aromatic rings. Fortunately, some methodology for incorporating heteroatoms into compounds related to 2 is $\operatorname{known}^{10 a, b}$ and we sought to apply this methodology to the functionalised dihydroisoquinolone fragments. Secondly, our FBDD projects are frequently challenged by having to work out methodology to access synthetic growth points or vectors in $3 \mathrm{D}$ space. One fragment may bind to different protein targets, requiring different synthetic vectors in each case, as deduced by examining the protein-fragment X-ray crystal structure. An attraction of the dihydroisoquinolone fragment template is the numerous positions available for synthetic elaboration during the fragment-to-lead stage; these are shown in Fig. 3 as blue arrows. The Rh(III) methodo- 
Table 2 Reaction with functionalised alkenes

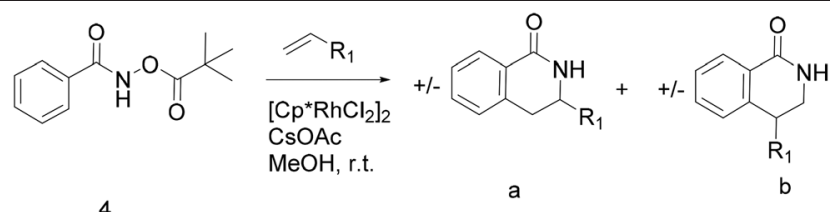

\begin{tabular}{|c|c|c|c|c|}
\hline Alkene & Product a & Product b & Isolated yield \% & $\begin{array}{l}\text { Regio-selectivity } \\
\text { (ratio a : b estimated by NMR) }\end{array}$ \\
\hline & & & 59 & $>20: 1$ \\
\hline & & & $a+b: 93$ & $1: 1$ \\
\hline & & & $\begin{array}{l}\text { 6a:42 } \\
\text { 6b:42 }\end{array}$ & $1: 1$ \\
\hline & & & 63 & $>20: 1$ \\
\hline & & & 74 & $>20: 1$ \\
\hline
\end{tabular}

logy has already been shown to permit several of these growth points into fragment $1 .^{9,10,10 c-e}$

\section{Results and discussion}

\section{Use of substituted alkenes to give polar functionality for protein binding and/or further synthetic elaboration (Table 2)}

Compound 4 is readily available following literature procedur$\mathrm{es}^{10 c}$ and was used to explore reactions with mono substituted alkenes. The alkenes selected were chosen to expand those previously described in the literature and allow introduction of new (protected) functional groups useful for subsequent transformations or protein binding interactions.

Reaction with $\mathrm{N}, \mathrm{N}$-dimethyl allylamine gives a single regioisomeric product, 3 (59\% after $24 \mathrm{~h}$, note long time required possibly due to the basic amine coordinating to the catalyst). This is the first example that we are aware of where an amino substituted alkene is used in this procedure. Compound 3 is interesting as a fragment itself, $\mathrm{HAC}=15, \mathrm{MW}=204, \operatorname{cog} \mathrm{P}=$ 1.3, measured solubility $\geq 5 \mathrm{mM}$, (Fig. 1). This led us to explore this alkene in more functionalised systems (see Tables 3 and 4).

The silyl protected allyl alcohol and Boc protected allyl amine gave the cyclised products $\mathbf{5 a} \mathbf{a} \mathbf{b}$ and $\mathbf{6 a} \mathbf{a} \mathbf{b}$ respectively as
Table 3 Ar-substituted hydroxamates plus $\mathbf{N}, \boldsymbol{N}$-dimethyl allylamine
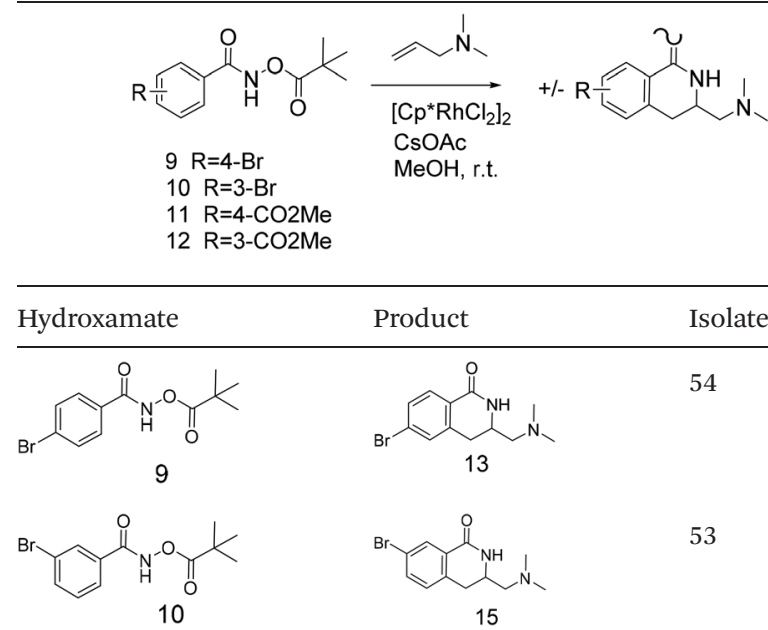

Product

Isolated yield \%
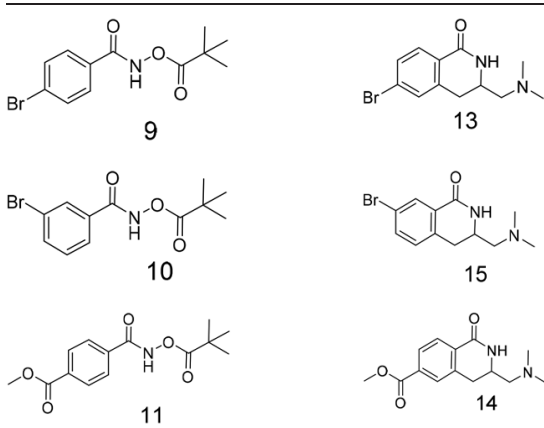<smiles>COC(=O)c1cccc(C(=O)NOC(=O)C(C)(C)C)c1</smiles>

12 
Table 4 Thiophene analogues

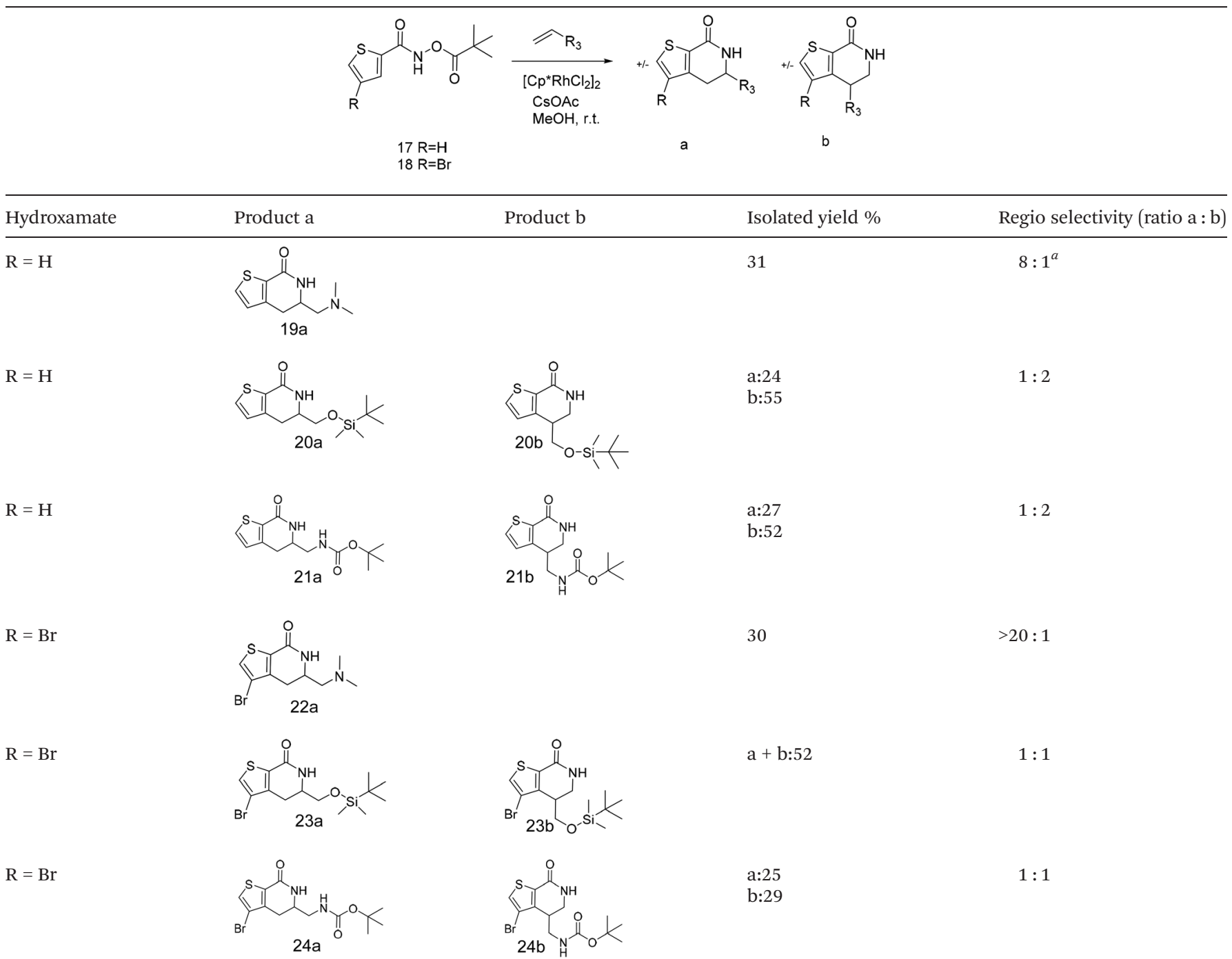

${ }^{a}$ Isomer ratio determined by LCMS, minor isomer not isolated.

1:1 mixtures of regioisomers in good yields. These protected hydroxyl and amino substituted analogues can be deprotected to provide groups capable of forming new polar binding interactions and/or synthetic growth vectors. Benzyl substituted acrylamide gives a single regioisomer, 7a (63\%). This is the first example that we are aware of using an amide in this transformation (but note that $7 \mathbf{a}$ has been synthesised previously by a different route ${ }^{13}$ and is commercially available in milligram quantities). If this growth vector is required, the formation of a single regioisomer is an advantage. Acrolein diethylacetal gives a single regioisomer, $8 \mathbf{a}(74 \%)$ and again the protected aldehyde can provide a handle for a range of subsequent transformations.

We selected aromatic bromides and esters for incorporation into the hydroxamates to probe the methodology for fragmentto-lead elaboration (Table 3). Note that compounds 13-16 are not designed to be fragments themselves. Rather, their synthesis builds confidence that if fragment $\mathbf{3}$ binds to a protein with an interaction that shows opportunity for elaboration via the meta or para positions, synthetic methodology is already established to follow-up rapidly.

Modest to good yields and a single regioisomer are observed for $\mathbf{1 3}, \mathbf{1 4}, \mathbf{1 6}$. The meta-bromo substituted analogue 10 gave a small amount of product corresponding to cyclisation onto the position ortho to the bromine. This product was not isolated in a pure form, but ${ }^{1} \mathrm{H}$ NMR of a mixed fraction was consistent with this isomer (see ESI $\dagger$ ).

There is some precedent for using the para-methyl ester substituted hydroxamate, $\mathbf{1 1}^{10 c, 14}$ but the meta-methyl ester substituted hydroxamate, $\mathbf{1 2}$ has not been reported previously.

In our hands preliminary attempts to cyclise with ortho $\mathrm{Br}$ or OMe substituted hydroxamates were unsuccessful perhaps 
due to unfavourable steric interactions between the ortho substituent and the hydroxamate carbonyl (data not shown). An ortho iodide substituent on a closely related system has been reported $^{15}$ but this remains an area requiring additional research.

\section{Application of methodology to heteroaromatic analogues (Table 4 and Scheme 1)}

Incorporating heteroatoms into aromatic rings of fragments is highly desirable in order to: modulate physicochemical properties ( $\log P$, solubility etc.); probe fragment binding interactions; increase opportunities for fragment-to-lead synthetic elaboration, and to subtly alter the growth vectors. Hence, we investigated three heterocycles commonly found in biologically active leads and drugs: thiophenes, thiazoles and pyridines.

There are a few reports of the Rh(III) methodology being applied to thiophenes ${ }^{11}$ and pyridines ${ }^{16}$ (compound 17 has been used with a vinyl ester ${ }^{11}$ ) but from a fragment perspective the scope of the methodology is limited and we are not aware of thiazoles being used previously.

The thiophenes in Table 4 are derivatised with the same (protected) polar groups used above: amines, alcohols and amides. The aromatic bromo substituents provide potential synthetic growth points for the fragment-to-lead stage.

$N, N$-Dimethyl allyl amine reacted with both the substituted and unsubstituted thiophenes to give 19a and 22a (31, 30\% yields unoptimised). Compound 19a can be considered as a fragment itself $(\mathrm{HAC}=14, \mathrm{MW}=210, \operatorname{clog} \mathrm{P}=1.1)$ and since aromatic sulphurs are known to form binding interactions with carbonyls they provide an additional protein binding possibility. Reaction of the thiophene hydroxamates $\mathbf{1 7}$ and $\mathbf{1 8}$ with the TBDMS protected allyl alcohol gives 20a,b and 23a,b respectively and Boc protected allyl amine gives 21a,b and 24a, b in good yields and with a similar isomer ratio.

Scheme 1 extends the method to thiazoles. The chloro thiazole hydroxamate, $\mathbf{2 5}$ was prepared using the standard conditions and treatment with TBDMS protected allyl alcohol
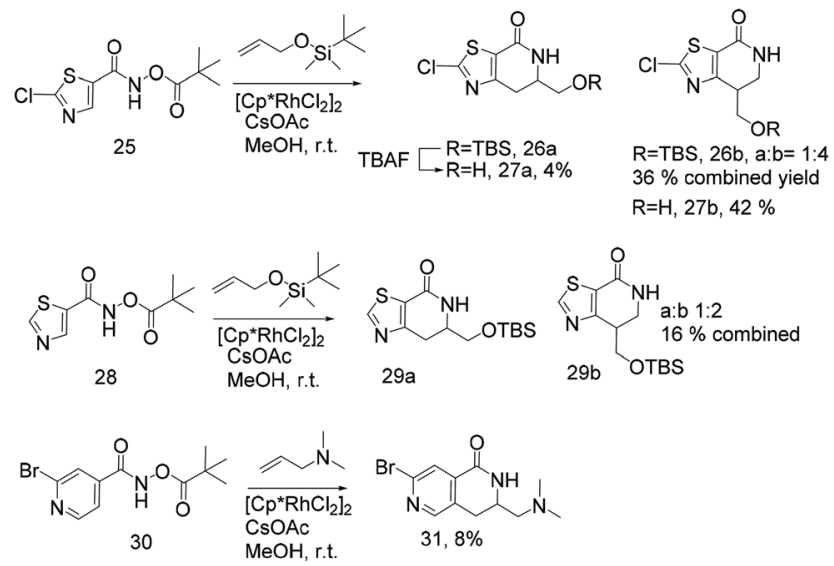

Scheme 1 generated the two expected isomers 26a and 26b in a 1:4 ratio. Removal of the silyl group produced a mixture of regioisomers that could be separated into $27 \mathbf{a}$ and $27 \mathbf{b}$, albeit in low yield (4\% and $42 \%$ respectively) (Scheme 1). Unoptimised attempts to use $N, N$-dimethyl allyl amine failed in this reaction. The TBDMS-protected alkene also reacted with the unsubstituted thiazole 28, although the unoptimised yield of 29a,b was low (16\%) and regioisomer b is the major product.

Based upon literature precedent this methodology was known to be less suitable for pyridyl analogues due to the lower reactivity of these electron deficient systems and formation of regioisomer mixtures. This has been overcome to some extent by the use of a pyridine $N$-oxide to increase the reactivity of the pyridine ring. ${ }^{10 a}$ Compound 30 (Scheme 1), synthesised following standard procedures, was treated with $\mathrm{N}, \mathrm{N}$-dimethyl allylamine to give a mixture of isomers and $\mathbf{3 1}$ was isolated by preparative HPLC but the (unoptimised) yield is only $8 \%$ and as previously noted, higher catalyst loading was used. Our results indicate that this methodology is not yet ideal for heterocycles and given their importance in drug discovery this is another area that would benefit from additional research.

\section{Conclusions}

The emergence of FBDD has created new demands for organic synthesis. Despite the apparent simplicity of fragment-like compounds they present significant and growing challenges, e.g., methodology to design and synthesise new fragments and methodology to grow fragments into high affinity chemical leads via synthetic growth points (vectors) according to the particular fragment-protein binding interactions. These two aspects are frequently rate limiting in FBDD.

This study identified the dihydroisoquinolones, 1-3 as having attractive fragment-like chemical properties (see Table 1). A published method to synthesise compound 2 utilising $\mathrm{Rh}$ (III) catalysed $\mathrm{C}-\mathrm{H}$ bond activation ${ }^{9,10 c}$ has been extended to increase the utility of this template for fragmentbased drug discovery. We have focused on:

- Adding polar side chains capable of exploring new binding interactions with proteins (tertiary amines and protected amines, alcohols and amides).

- Incorporating $\mathrm{S}$ and $\mathrm{N}$ heteroatoms into the aromatic ring to modulate $\log P$, solubility, synthetic growth vectors etc.

- Adding functional groups that can be used as synthetic points for fragment growth during fragment-to-lead optimisation (aromatic bromides and esters).

These results illustrate frequently encountered synthetic organic chemistry challenges that we face in FBDD including:

- Synthetic methodology that is not exemplified in the presence of heterocyclic aromatics and polar functional groups e.g. amines.

- Synthetic methodology that is not exemplified for water soluble compounds (we require low lipophilicity, Table 1). 
- Requirement for multiple, synthetically accessible fragment growth positions (Fig. 3) and methodology that allows regio- and stereo-selective fragment growth in the presence of polar functionality.

Some of the chemistry methodology challenges for FBDD are similar to other drug discovery techniques including HTS, e.g. the desire to incorporate polar side chains and heteroatoms into lead molecules. ${ }^{17}$ Others, such as the small size and lipophilicity of fragments; the requirement for synthetic vectors in multiple directions; and the drive to use X-ray crystallography to design bespoke synthetic targets, are more evident in FBDD laboratories. We see a pressing need for even more synthetic organic chemists to engage with these challenges.

\section{Experimental}

\section{General experimental}

All reactions were carried out without exclusion of air or moisture unless otherwise stated. Commercial solvents and reagents were used without further purification. Reactions were monitored by HPLC-MS on an Agilent 1200 series instrument, coupled with an Agilent 1200 MWD SL UV detector and Agilent 6140 single quadrupole mass detector. Normal phase flash chromatography was performed using a Biotage Isolera and silica SNAP cartridges. Petrol refers to petroleum ether (b.p. $40-60^{\circ} \mathrm{C}$ ). Reverse phase chromatography was performed using a Biotage SP4 and Biotage C18 Ultra cartridges with an acetonitrile in water gradient, without use of modifiers. Preparative HPLC was performed on an Agilent 1260 instrument, using Waters prep columns (Atlantis prep T3 OBD $5 \mu \mathrm{m} 100 \times$ $19 \mathrm{~mm}$, Sunfire prep C18 OBD $5 \mu \mathrm{m} 100 \times 19 \mathrm{~mm}$ or XBridge C18 $5 \mu \mathrm{m}$ OBD $100 \times 19 \mathrm{~mm}$ ). HRMS (ESI) spectra were recorded on an Agilent 6550 QTOF instrument.

${ }^{1} \mathrm{H},{ }^{13} \mathrm{C},{ }^{13} \mathrm{C}$-Dept, COSY, HSQC and HMBC NMR spectra were recorded using Bruker $400 \mathrm{MHz}$ or $500 \mathrm{MHz}$ spectrometers $\left(\mathrm{CDCl}_{3}\right.$ or $\mathrm{d}_{6}$-DMSO as solvent). Chemical shifts for ${ }^{1} \mathrm{H}$ and ${ }^{13} \mathrm{C}$ NMR spectra are reported as $\delta$ in units of parts per million (ppm) downfield from $\mathrm{SiMe}_{4}(\delta 0.0)$ using the chemical shifts of the residual solvent peaks. Multiplicities are given as: $\mathrm{s}$ (singlet); brs (broad singlet); d (doublet); t (triplet); q (quartet); dd (doublets of doublet); td (triplet of doublet); $\mathrm{m}$ (multiplets) etc. Coupling constants are reported as $J$ values in Hz. ${ }^{13} \mathrm{C}$ chemical shifts were measured using direct ${ }^{13} \mathrm{C}$ NMR or via 2D HSQC and HMBC spectra.

\section{Preparation of $\boldsymbol{N}$-pivaloyloxy amide starting materials}

General procedure A. Step 1: to a suspension of the carboxylic acid (20 mmol, 1.0 eq.) in dry $\mathrm{CH}_{2} \mathrm{Cl}_{2}(20 \mathrm{~mL})$ at room temperature under a nitrogen atmosphere was added a catalytic amount of dry DMF (4 drops). Oxalyl chloride $(15 \mathrm{~mL}$, $30 \mathrm{mmol}, 1.5$ eq., $2 \mathrm{M}$ soln in DCM) was added dropwise over about 20 minutes with care as effervescence occurs. The reaction was allowed to stir at room temperature until completion which was judged to be when no further effervescence could be seen and in some cases, the solution became homogeneous. The solvent was then removed under reduced pressure to afford the corresponding crude acid chloride.

Step 2: hydroxylamine hydrochloride $(1.39 \mathrm{~g}, 20 \mathrm{mmol}$, 1 eq.) was added to a biphasic mixture of $\mathrm{K}_{2} \mathrm{CO}_{3}(5.52 \mathrm{~g}$, $20 \mathrm{mmol}, 2.0$ eq.) in a $2: 1$ mixture of EtOAc $(40 \mathrm{~mL})$ and $\mathrm{H}_{2} \mathrm{O}$ $(20 \mathrm{~mL})$. The resulting solution was cooled to $0{ }^{\circ} \mathrm{C}$ followed by dropwise addition of the crude acid chloride dissolved in a minimum amount of EtOAc. The flask containing the acid chloride was then rinsed with additional EtOAc. The reaction was allowed to warm to room temperature which in most cases resulted in formation of a thick white suspension of the hydroxamic acid. The reaction was stirred for $4 \mathrm{~h}$ to allow complete conversion of the acid chloride to hydroxamic acid then pivaloyl chloride $(2.46 \mathrm{ml}, 20 \mathrm{mmol})$ was added dropwise. The reaction can be monitored by TLC and HPLC and also the thick white precipitate dissolves as the reaction proceeds and the hydroxamic acid is consumed. Further pivaloyl chloride can be added if required. The phases were separated and the aqueous phase was extracted twice with EtOAc. The combined organic layers were dried over $\mathrm{MgSO}_{4}$, filtered, and evaporated under reduced pressure. The crude products were purified by flash column chromatography using an appropriate solvent mixture of petrol/EtOAc as eluent.

Phenylformamido 2,2-dimethylpropanoate (4). ${ }^{18}$ Triethyl amine (2.03 ml, $14.59 \mathrm{mmol}, 1$ equiv.) was added to a suspension of $N$-hydroxybenzamide $(2.0 \mathrm{~g}, 14.59 \mathrm{mmol}, 1$ equiv.) in dichloromethane $(30 \mathrm{~mL})$. The reaction mixture was cooled to $0{ }^{\circ} \mathrm{C}$ in an ice bath then pivaloyl chloride $(1.79 \mathrm{~mL}$, 14.59 mmol, 1 equiv.) was added dropwise. The resulting mixture was allowed to warm to room temperature and stirred for 2 hours. The reaction was diluted with DCM, transferred to a separating funnel and washed with water then brine. The organic layer was dried over $\mathrm{MgSO}_{4}$, filtered and evaporated under reduced pressure. The crude material was purified by flash chromatography using a gradient of $0-30 \%$ ethyl acetate in petrol as eluent. The product was obtained as a white solid $\left(2.4 \mathrm{~g}, 74 \%\right.$ yield). $\delta_{\mathrm{H}}(400 \mathrm{MHz}$, chloroform- $d) 9.43(1 \mathrm{H}, \mathrm{s})$, 7.89-7.72 (2 H, m), 7.62-7.50 (1 H, m), 7.50-7.38 (2 H, m), 1.35 $(9 \mathrm{H}, \mathrm{s}) . \delta_{\mathrm{C}}(101 \mathrm{MHz}$, chloroform- $d$ ) 177.17, 166.92, 132.81, 131.08, 128.93, 127.61, 38.61, 27.17.

(4-Bromophenyl)formamido 2,2 -dimethylpropanoate (9). ${ }^{11}$ Synthesised according to general procedure A, step 2 on a $20 \mathrm{mmol}$ scale, starting with commercially available acid chloride. The crude material was purified by flash chromatography using a gradient of $0-20 \%$ ethyl acetate in petrol as eluent. The product was obtained as a white solid ( $4.8 \mathrm{~g}, 80 \%$ yield). $\delta_{\mathrm{H}}\left(400 \mathrm{MHz}, \mathrm{DMSO}-d_{6}\right) 12.37(1 \mathrm{H}, \mathrm{s}), 7.75(4 \mathrm{H}, \mathrm{s}), 1.28$ $(9 \mathrm{H}, \mathrm{s})$.

(3-Bromophenyl)formamido 2,2-dimethylpropanoate (10). ${ }^{11,16}$ Synthesised according to general procedure A, step 2 on a $20 \mathrm{mmol}$ scale, starting with commercially available acid chloride. The crude material was purified by flash chromatography using a gradient of $0-30 \%$ ethyl acetate in petrol as eluent then recrystallised from $\mathrm{Et}_{2} \mathrm{O}$ /petrol. The product was obtained as a white solid $\left(2.4 \mathrm{~g}, 40 \%\right.$ yield). $\delta_{\mathrm{H}}\left(400 \mathrm{MHz}\right.$, DMSO- $\left.d_{6}\right)$ 
12.41 (1 H, brs), 7.97 (1 H, t, $J$ 1.9), 7.82 ( $2 \mathrm{H}$, dd, $J$ 7.9, 1.9), 7.50 (1 H, t, J 7.9), 1.29 (9 H, s).

Methyl 4-\{[(2,2-dimethylpropanoyl)oxy]carbamoyl\}benzoate (11). Synthesised according to general procedure A on a $20 \mathrm{mmol}$ scale, starting with commercially available carboxylic acid. The crude material was purified by flash chromatography using a gradient of $0-30 \%$ ethyl acetate in petrol as eluent. The product was obtained as a white solid $(2.837 \mathrm{~g}, 50 \%$ yield over 3 steps $). \quad \delta_{\mathrm{H}}\left(400 \mathrm{MHz}, \mathrm{DMSO}-d_{6}\right) 12.47$ (1 H, brs), 8.18-8.02 (2 H, m), 8.02-7.87 (2 H, m), 3.89 (3 H, s), 1.29 (9 H, s). $\delta_{\mathrm{C}}\left(101 \mathrm{MHz}, \mathrm{DMSO}-d_{6}\right) 175.51,165.49,163.60,135.15$, 132.61, 129.36, 127.71, 52.39, 37.78, 26.76. HRMS (ESI-QTOF): $m / z[\mathrm{M}+\mathrm{H}]^{+}$Calcd for $\mathrm{C}_{14} \mathrm{H}_{17} \mathrm{NO}_{5}$ 280.1185; found: 279.1122 $\delta=3.57 \mathrm{ppm}$.

Methyl 3-\{[(2,2-dimethylpropanoyl)oxy]carbamoyl\}benzoate (12). ${ }^{11}$ Synthesised according to general procedure $A$ on a $20 \mathrm{mmol}$ scale, starting with commercially available carboxylic acid. The crude material was purified by flash chromatography using a gradient of $0-30 \%$ ethyl acetate in petrol as eluent. The product was obtained as a white solid $(1.477 \mathrm{~g}, 26 \%$ yield over 3 steps). ${ }^{1} \mathrm{H}$ NMR (400 MHz, DMSO- $\left.d_{6}\right) \delta 12.49$ (1 H, brs), 8.42 (1 H, t, $J$ 1.6), 8.16 (1 H, dt, $J$ 7.9, 1.6), 8.08 (1 H, dt, $J$ 7.9, 1.6), 7.69 (1 H, t, J 7.9), 3.90 (3 H, s), 1.29 (9 H, s). ${ }^{13} \mathrm{C} \mathrm{NMR}$ (101 MHz, DMSO- $d_{6}$ ) $\delta 175.57,165.48,163.53,132.54,131.90$, 131.64, 130.04, 129.33, 127.92, 52.37, 37.78, 26.76. HRMS (ESI-QTOF): $m / z[\mathrm{M}+\mathrm{H}]^{+}$Calcd for $\mathrm{C}_{14} \mathrm{H}_{17} \mathrm{NO}_{5}$ 280.1185; found: $280.1197 . \delta=4.28 \mathrm{ppm}$.

(Thiophen-2-yl)formamido 2,2-dimethylpropanoate (17). Triethyl amine $(0.972 \mathrm{ml}, 6.99 \mathrm{mmol}, 1$ equiv. $)$ was added to a suspension of $N$-hydroxythiophene-2-carboxamide $(1.0 \mathrm{~g}$, $6.99 \mathrm{mmol}, 1$ equiv.) in THF (10 mL). The reaction mixture was cooled to $0{ }^{\circ} \mathrm{C}$ in an ice bath then pivaloyl chloride $(0.86 \mathrm{~mL}$, 6.99 mmol, 1 equiv.) was added dropwise. The resulting mixture was allowed to warm to room temperature and stirred for 2 hours. The reaction was diluted with EtOAc, transferred to a separating funnel and washed with water then brine. The organic layer was dried over $\mathrm{MgSO}_{4}$, filtered and evaporated under reduced pressure. The crude material was purified by flash chromatography using a gradient of $0-30 \%$ ethyl acetate in petrol as eluent. The product was obtained as an off-white solid (1.22 g, 77\% yield). $\delta_{\mathrm{H}}\left(400 \mathrm{MHz}, \mathrm{DMSO}-d_{6}\right)$ 12.25 ( $1 \mathrm{H}, \mathrm{brs}), 7.88$ ( $1 \mathrm{H}$, dd, $J$ 5.0, 1.2), 7.74 (1 H, dd, $J$ 3.7, 1.2), 7.20 (1 $\mathrm{H}, \mathrm{dd}, J 5.0,3.7), 1.28$ (9 H, s). $\delta_{\mathrm{C}}\left(101 \mathrm{MHz}, \mathrm{DMSO}-d_{6}\right) 175.67,159.83,134.95,131.96$, 129.38, 128.12, 37.75, 26.75. HRMS (ESI-QTOF): $m / z[\mathrm{M}+\mathrm{H}]^{+}$ Calcd for $\mathrm{C}_{10} \mathrm{H}_{13} \mathrm{NO}_{3} \mathrm{~S}$ 228.0689; found: 228.0692. $\delta=$ $1.32 \mathrm{ppm}$.

(4-Bromothiophen-2-yl)formamido 2,2-dimethylpropanoate (18). Synthesised according to general procedure A, step 2 on a $9.66 \mathrm{mmol}$ scale, starting with commercially available acid chloride. The crude material was purified by flash chromatography using a gradient of $0-30 \%$ ethyl acetate in petrol as eluent. The product was obtained as an off-white solid (1.5 g, $50 \%$ yield). $\delta_{\mathrm{H}}\left(400 \mathrm{MHz}, \mathrm{DMSO}-d_{6}\right) 12.43(1 \mathrm{H}, \mathrm{brs}), 8.03(1 \mathrm{H}$, d, $J 1.5), 7.72$ (1 H, d, J 1.5), 1.28 (9 H, s). $\delta_{\mathrm{C}}(101 \mathrm{MHz}, \mathrm{DMSO})$ 176.03 , 158.91, 136.76, 131.55, 130.27, 109.61, 38.29, 27.22.
HRMS (ESI-QTOF): $m / z[\mathrm{M}+\mathrm{H}]^{+}$Calcd for $\mathrm{C}_{10} \mathrm{H}_{12} \mathrm{BrNO}_{3} \mathrm{~S}$ 305.9794; found: 305.9802. $\delta=2.61 \mathrm{ppm}$.

(2-Chloro-1,3-thiazol-5-yl)formamido 2,2-dimethylpropanoate (25). Synthesised according to general procedure A on a $12 \mathrm{mmol}$ scale, starting with commercially available carboxylic acid. The crude material was purified by flash chromatography using a gradient of $0-50 \%$ ethyl acetate in petrol as eluent. The product obtained is an off white solid (1.818 g, 57\% yield over 3 steps). $\delta_{\mathrm{H}}\left(400 \mathrm{MHz}, \mathrm{DMSO}-d_{6}\right) 12.69$ (1 H, brs), 8.21 $(1 \mathrm{H}, \mathrm{s}), 1.27$ (9 H, s). $\delta_{\mathrm{C}}\left(101 \mathrm{MHz}, \mathrm{DMSO}-d_{6}\right) 175.36,157.11$, 154.70, 142.98, 133.24, 37.80, 26.67. HRMS (ESI-QTOF): $\mathrm{m} / \mathrm{z}$ $[\mathrm{M}+\mathrm{H}]^{+}$Calcd for $\mathrm{C}_{9} \mathrm{H}_{11} \mathrm{ClN}_{2} \mathrm{O}_{3} \mathrm{~S}$ 263.0252; found: 263.0261 . $\delta=3.42 \mathrm{ppm}$.

(1,3-Thiazol-5-yl)formamido 2,2-dimethylpropanoate (28). Synthesised according to general procedure A, step 2 on a $15.5 \mathrm{mmol}$ scale, starting with commercially available acid chloride. The crude material was purified by flash chromatography using a gradient of $0-100 \%$ ethyl acetate in petrol as eluent. The product obtained is a yellow oil $(0.502 \mathrm{~g}, 14 \%$ yield). $\delta_{\mathrm{H}}\left(400 \mathrm{MHz}, \mathrm{DMSO}-d_{6}\right) 9.75(1 \mathrm{H}, \mathrm{brs}), 9.20(1 \mathrm{H}, \mathrm{d}$, $J ~ 0.7), 8.32$ (1 H, d, $J 0.7), 1.25$ (9 H, s). $\delta_{\mathrm{C}}\left(101 \mathrm{MHz}, \mathrm{DMSO}-d_{6}\right)$ $175.51,158.92,157.47,143.90,132.64$, 37.82, 26.90. HRMS (ESI-QTOF): $m / z[\mathrm{M}+\mathrm{H}]^{+}$Calcd for $\mathrm{C}_{9} \mathrm{H}_{12} \mathrm{~N}_{2} \mathrm{O}_{3} \mathrm{~S}$ 229.0641; found: 228.0578. $\delta=4.37 \mathrm{ppm}$.

(2-Bromopyridin-4-yl)formamido 2,2-dimethylpropanoate (30). Synthesised according to general procedure $\mathrm{A}$ on a $20 \mathrm{mmol}$ scale, starting with commercially available carboxylic acid. The crude material was purified by flash chromatography using a gradient of $0-20 \%$ ethyl acetate in petrol as eluent. The product was obtained as an off-white solid $(2.21 \mathrm{~g}, 36 \%$ yield over 3 steps). $\delta_{\mathrm{H}}\left(400 \mathrm{MHz}, \mathrm{DMSO}-d_{6}\right) 12.75$ (1 H, brs), 8.60 (1 H, dd, $J$ 5.1, 0.8), 7.94 (1 H, brs), 7.76 (1 H, dd, J 5.1, 1.5), 1.29 (9 H, s). $\delta_{\mathrm{C}}\left(101 \mathrm{MHz}, \mathrm{DMSO}-d_{6}\right) 175.24,161.05$, $151.53,141.87,141.20,125.48,120.96$, 37.81, 26.69. HRMS (ESI-QTOF): $m / z[\mathrm{M}+\mathrm{H}]^{+}$Calcd for $\mathrm{C}_{11} \mathrm{H}_{13} \mathrm{BrN}_{2} \mathrm{O}_{3}$ 301.0182; found: $301.0194 . \delta=3.99 \mathrm{ppm}$.

\section{Synthesis of 3,4 dihydroisoquinolones}

General procedure B. Without any particular precautions to exclude oxygen or moisture, the pivaloyl-protected hydroxamic acid (1 equiv.), [Cp* $\left.\mathrm{RhCl}_{2}\right]_{2}(1 \mathrm{~mol} \%)$ and CsOAc (2 equiv.) were weighed into a $5 \mathrm{~mL}$ CEM microwave tube equipped with a stirrer bar. $\mathrm{MeOH}(0.2 \mathrm{M})$ was then added followed immediately by the alkene (1.1 equiv.). The reaction was stirred at room temperature for 16 hours or if necessary, heated up to $65^{\circ} \mathrm{C}$ in the CEM microwave for between $2-7$ hours. The reaction was diluted with EtOAc washed with $\mathrm{Na}_{2} \mathrm{CO}_{3}$ sat. aq. then brine. The combined organic layers were dried over $\mathrm{MgSO}_{4}$, filtered and evaporated under reduced pressure. The crude products were purified by flash column chromatography on a Biotage using an appropriate solvent mixture of petrol/EtOAc or EtOAc/MeOH as eluent.

3-[(Dimethylamino)methyl]-1,2,3,4-tetrahydroisoquinolin-1one (3). Synthesised following general procedure B. The reaction was carried out at room temperature and the crude material was purified by flash column chromatography using a 
gradient of $0-10 \% \mathrm{MeOH}$ in EtOAc. The desired compound was obtained as a brown solid in $59 \%$ yield $(55 \mathrm{mg}$ ) from phenylformamido 2,2-dimethylpropanoate (4) $(0.45 \mathrm{mmol}$, $100 \mathrm{mg}, 1$ equiv.). $\delta_{\mathrm{H}}\left(400 \mathrm{MHz}, \mathrm{DMSO}-d_{6}\right) 7.88-7.81(1 \mathrm{H}, \mathrm{m})$, 7.48 (1 H, td, $J$ 7.5, 1.5), 7.41 (1 H, brs), 7.37-7.32 (1 H, m), 7.32-7.28 (1 H, m), 3.72 (1 H, dtdd, J 9.0, 7.1, 4.8, 2.1), 3.01 (1 H, dd, J 15.8, 4.8), 2.79 (1 H, dd, J 15.8, 9.0), 2.35 (1 H, dd, $J$ 12.0, 7.1), 2.27 (1 H, dd, J 12.0, 7.1), 2.18 (s, 6H). $\delta_{\mathrm{C}}(101 \mathrm{MHz}$, DMSO- $\left.d_{6}\right) 164.60,138.50,132.37,129.04,128.24,127.38$, 127.13, 63.28, 48.24, 45.98, 31.90. HRMS (ESI-QTOF): $\mathrm{m} / \mathrm{z}$ $[\mathrm{M}+\mathrm{H}]^{+}$Calcd for $\mathrm{C}_{12} \mathrm{H}_{16} \mathrm{~N}_{2} \mathrm{O}$ 205.1335; found: 205.1349. $\delta=$ $6.82 \mathrm{ppm}$.

3-\{[(tert-Butyldimethylsilyl)oxy]methyl $\}-1,2,3,4$-tetrahydroisoquinolin-1-one (5a). Synthesised following general procedure B. The reaction was carried out at room temperature and the crude material was purified by flash column chromatography using a gradient of $0-50 \%$ EtOAc in petrol. The desired compound was obtained as a 1:1 mixture of regioisomers (5a and 5b) that were inseparable by column chromatography. The mixture was a white solid, 93\% combined yield (123 mg) from phenylformamido 2,2-dimethylpropanoate (4) (0.45 mmol, $100 \mathrm{mg}, 1$ equiv.). Partial separation of the regioisomers was possible by reverse phase chromatography, eluting 45-65\% MeCN in water to give isomer $5 \mathbf{a}(18 \mathrm{mg})$ plus $\mathbf{5 b}(16 \mathrm{mg})$ in pure form with a mixed fraction $(60 \mathrm{mg}) . \delta_{\mathrm{H}}(400 \mathrm{MHz}$, chloroform-d) 8.08 (1 H, dd, $J$ 7.6, 1.5), 7.44 (1 H, td, $J$ 7.6, 1.5), 7.39-7.30 (1 H, m), 7.22-7.16 (1 H, m), 6.25 (1 H, brs), 3.87-3.78 (1 H, m), 3.74 ( $1 \mathrm{H}, \mathrm{dd}, J 10.0,1.0), 3.60$ (1 H, dd, $J$ 10.0, 8.4), 2.93-2.77 (2 H, m), 0.90 ( $9 \mathrm{H}, \mathrm{s}), 0.08$ (3 H, s), 0.07 $(3 \mathrm{H}, \mathrm{s}) . \delta_{\mathrm{C}}\left(101 \mathrm{MHz}, \mathrm{CDCl}_{3}\right) 165.74,137.25,132.26,128.69$, 128.14, 127.46, 127.08, 65.66, 52.68, 30.27, 25.83, 18.27, -5.45. HRMS (ESI-QTOF): $m / z[\mathrm{M}+\mathrm{H}]^{+}$Calcd for $\mathrm{C}_{16} \mathrm{H}_{25} \mathrm{NO}_{2} \mathrm{Si}$ 292.1728; found 292.1736. $\delta=2.53 \mathrm{ppm}$.

4-\{[(tert-Butyldimethylsilyl)oxy]methyl $\}-1,2,3,4$-tetrahydroisoquinolin-1-one (5b). See above. $\delta_{\mathrm{H}}(400 \mathrm{MHz}$, chloroform- $d$ ) 8.08 (1 H, dd, $J$ 7.6, 1.5), 7.47 (1 H, td, J 7.6, 1.5), $7.38(1 \mathrm{H}, \mathrm{td}$, $J$ 7.6, 1.5), 7.27-7.21 (1 H, m), 5.96 (1 H, brs), 3.75 (1 H, dd, $J$ 13.6, 10.0), 3.70-3.66 (2 H, m), 3.66 (1 H, dd, $J$ 10.0, 5.4), 3.08-2.97 (1 H, m), $0.89(9 \mathrm{H}, \mathrm{s}), 0.03(3 \mathrm{H}, \mathrm{s}), 0.03(3 \mathrm{H}, \mathrm{s}) . \delta_{\mathrm{C}}$ $\left(101 \mathrm{MHz}, \mathrm{CDCl}_{3}\right) 165.74,137.25,132.26,128.69,128.14$, $127.77,127.53,63.58,40.61,40.78,25.83,18.27,-5.45$. HRMS (ESI-QTOF): $m / z[\mathrm{M}+\mathrm{H}]^{+}$Calcd for $\mathrm{C}_{16} \mathrm{H}_{25} \mathrm{NO}_{2} \mathrm{Si} 292.1728$; found 292.1736. $\delta=2.62 \mathrm{ppm}$.

tert-Butyl $\quad N$-[(1-oxo-1,2,3,4-tetrahydroisoquinolin-3-yl) methyl]carbamate (6a). Synthesised following general procedure B. The reaction was carried out at room temperature and the crude material was purified by flash column chromatography using a gradient of $0-50 \%$ EtOAc in petrol. The desired compound was obtained as a white solid in $42 \%$ yield (53 $\mathrm{mg}$ ) from phenylformamido 2,2-dimethylpropanoate (4) (0.45 mmol, $100 \mathrm{mg}, 1$ equiv.). $\delta_{\mathrm{H}}\left(400 \mathrm{MHz}, \mathrm{DMSO}-d_{6}\right) 7.82$ (1 H, dd, J 7.5, 1.5), 7.80-7.75 (1 H, m), 7.47 (1 H, td, $J 7.5,1.5)$, 7.33 ( $1 \mathrm{H}, \mathrm{td}, J 7.5,1.2), 7.28$ (1 H, d, J 7.5), 6.96 (1 H, t, J 5.9), 3.66-3.47 (1 H, m), 3.12-2.98 (2 H, m), 2.97 (1 H, dd, J 16.0, 5.2), 2.76 (1 H, dd, J 16.0, 8.2), 1.38 (9 H, s). $\delta_{\mathrm{C}}(101 \mathrm{MHz}$, DMSO- $\left.d_{6}\right) 164.02$, 155.62, 137.52, 131.65, 128.53, 127.79,
126.60, 126.44, 77.86, 50.16, 43.34, 30.34, 27.94. HRMS (ESI-QTOF): $m / z[\mathrm{M}+\mathrm{H}]^{+}$Calcd for $\mathrm{C}_{15} \mathrm{H}_{20} \mathrm{~N}_{2} \mathrm{O}_{3}$ 277.1547; found: $277.1558 . \delta=3.97 \mathrm{ppm}$.

tert-Butyl $\quad N$-[(1-oxo-1,2,3,4-tetrahydroisoquinolin-4-yl) methyl]carbamate (6b). Synthesis and purification described for $\mathbf{6 a}$. Compound $\mathbf{6 b}$ was obtained as a white solid in $42 \%$ yield (54 mg) from phenylformamido 2,2-dimethylpropanoate (4) (0.45 mmol, $100 \mathrm{mg}, 1$ equiv.). $\delta_{\mathrm{H}}\left(400 \mathrm{MHz}, \mathrm{DMSO}-d_{6}\right) 7.85$ (1 H, dd, J 7.6, 1.5), 7.74 (1 H, d, J 4.4), 7.49 (1 H, td, J 7.6, 1.5), 7.37 (1 H, td, J 7.6, 1.3), 7.27 (1 H, d, J 7.6), 7.03 (1 H, t, J 5.4), 3.48 (1 H, dd, J 12.7, 4.4), 3.31-3.23 (1 H, m), 3.15-3.05 (2 H, $\mathrm{m}), 3.03-2.94(1 \mathrm{H}, \mathrm{m}), 1.37(9 \mathrm{H}, \mathrm{s}) . \delta_{\mathrm{C}}\left(101 \mathrm{MHz}, \mathrm{DMSO}-d_{6}\right)$ 163.80 , 155.46, 140.29, 131.48, 128.61, 126.91, 126.81, 127.36, 77.61, 40.67, 42.22, 36.89, 28.00. HRMS (ESI-QTOF): $\mathrm{m} / \mathrm{z}$ $[\mathrm{M}+\mathrm{H}]^{+}$Calcd for $\mathrm{C}_{15} \mathrm{H}_{20} \mathrm{~N}_{2} \mathrm{O}_{3}$ 277.1547; found: 277.155. $\delta=$ $1.08 \mathrm{ppm}$.

$N$-Benzyl-1-oxo-1,2,3,4-tetrahydroisoquinoline-3-carboxamide (7a). Synthesised following general procedure B. The reaction was carried out at room temperature and the crude material was purified by flash column chromatography using a gradient of $0-50 \%$ EtOAc in petrol. The desired compound was obtained as a white solid in $63 \%$ yield $(40 \mathrm{mg}$ ) from phenylformamido 2,2-dimethylpropanoate (4) (0.225 mmol, $50 \mathrm{mg}$, 1 equiv.). $\delta_{\mathrm{H}}\left(500 \mathrm{MHz}, \mathrm{DMSO}-d_{6}\right) 8.50(1 \mathrm{H}, \mathrm{t}, J 6.0), 7.98(1 \mathrm{H}$, d, $J$ 4.1), 7.83 (1 H, dd, J 7.6, 1.5), 7.47 (1 H, td, J 7.6, 1.5), 7.35 (1 H, t, J 7.6), 7.27 (1 H, d, J 7.6), 7.25-7.15 (3 H, m), 7.09-6.98 (2 H, m), 4.32-4.12 (3 H, m), 3.29 (1 H, dd, $J$ 16.0, 6.3), 3.16 $(1 \mathrm{H}, \mathrm{dd}, J 16.0,4.4) . \delta_{\mathrm{C}}\left(126 \mathrm{MHz}, \mathrm{DMSO}-d_{6}\right) 170.70,164.21$, 139.12, 136.63, 131.57, 129.01, 127.92, 127.42, 126.67, 126.63, 126.59, 126.46, 52.69, 41.89, 30.98. HRMS (ESI-QTOF): $\mathrm{m} / \mathrm{z}$ $[\mathrm{M}+\mathrm{H}]^{+}$Calcd for $\mathrm{C}_{17} \mathrm{H}_{16} \mathrm{~N}_{2} \mathrm{O}_{2} 281.1285$; found: $281.1298 . \delta=$ $4.62 \mathrm{ppm}$.

3-(Diethoxymethyl)-1,2,3,4-tetrahydroisoquinolin-1-one (8a). Synthesised following general procedure B. The reaction was carried out at room temperature and the crude material was purified by flash column chromatography using a gradient of 0-50\% EtOAc in petrol. The desired compound was obtained as a yellow solid in $71 \%$ yield $(40 \mathrm{mg}$ ) from phenylformamido 2,2-dimethylpropanoate (4) (0.225 mmol, $50 \mathrm{mg}, 1$ equiv.). $\delta_{\mathrm{H}}$ $\left(500 \mathrm{MHz}, \mathrm{DMSO}-d_{6}\right) 7.83$ (1 H, dd, $J$ 7.6, 1.4), 7.65-7.603 $(1 \mathrm{H}$, $\mathrm{m}), 7.46$ (1 H, td, J 7.6, 1.5), $7.32(1 \mathrm{H}, \mathrm{td}, J$ 7.6, 1.3), $7.31(1 \mathrm{H}$, d, $J$ 7.6), 4.32 (1 H, d, J 6.3), 3.69-3.53 (3 H, m), 3.46 (2 H, dq, $J$ 9.6, 6.9), 3.04 (1 H, dd, $J$ 16.2, 5.7), 2.93 (1 H, dd, $J$ 16.2, 6.9), $1.15-1.03(6 \mathrm{H}, \mathrm{m}) . \delta_{\mathrm{C}}\left(126 \mathrm{MHz}, \mathrm{DMSO}-d_{6}\right) 164.02,137.58$, $132.06,131.71,127.13,126.58,102.44,62.53$, 51.89, 27.93, 14.98. HRMS (ESI-QTOF): $m / z[\mathrm{M}+\mathrm{H}]^{+}$Calcd for 250.1438; found: $250.1454 . \delta=6.40 \mathrm{ppm}$.

6-Bromo-3-[(dimethylamino)methyl]-1,2,3,4-tetrahydroisoquinolin-1-one (13). Synthesised following general procedure B. The reaction was carried out at room temperature and the crude material was purified by flash column chromatography using a gradient of $0-10 \% \mathrm{MeOH}$ in EtOAc. The desired compound was obtained as a brown solid in 54\% yield (70 mg) from (4-bromophenyl)formamido 2,2-dimethylpropanoate (9) (0.45 mmol, $135 \mathrm{mg}, 1$ equiv.). $\delta_{\mathrm{H}}\left(400 \mathrm{MHz}, \mathrm{DMSO}-d_{6}\right) 7.75$ (1 H, d, J 8.2), 7.58 (1 H, d, J 2.0), 7.55 (1 H, br s), 7.53 (1 H, dd, 
$J$ 8.2, 2.0), 3.71 (1 H, dtdd, $J$ 8.7, 7.1, 4.9, 2.2), 3.02 (1 H, dd, $J$ 16.0, 4.9), 2.79 (1 H, dd, $J$ 16.0, 8.7), 2.33 (1 H, dd, $J$ 12.1, 7.1), $2.25(1 \mathrm{H}, \mathrm{dd}, J 12.1,7.1), 2.16(6 \mathrm{H}, \mathrm{s}) . \delta_{\mathrm{C}}\left(101 \mathrm{MHz}, \mathrm{DMSO}-d_{6}\right)$ 163.22, 140.42, 130.29, 129.50, 128.88, 128.33, 125.44, 62.44, 47.51, 45.25, 30.78. HRMS (ESI-QTOF): $m / z[\mathrm{M}+\mathrm{H}]^{+}$Calcd for $\mathrm{C}_{12} \mathrm{H}_{15} \mathrm{BrN}_{2} \mathrm{O} 283.0441$; found: 283.0448. $\delta=2.47 \mathrm{ppm}$.

Methyl 3-[(dimethylamino)methyl]-1-oxo-1,2,3,4-tetrahydroisoquinoline-6-carboxylate (14). Synthesised following general procedure B. The reaction was carried out at room temperature and the crude material was purified by flash column chromatography using a gradient of $0-10 \% \mathrm{MeOH}$ in EtOAc. The desired compound was obtained as a brown solid in $84 \%$ yield (100 mg) from methyl 4-\{[(2,2-dimethylpropanoyl)oxy]carbamoyl benzoate (11) (0.45 mmol, $125 \mathrm{mg}, 1$ equiv.). $\delta_{\mathrm{H}}$ (400 MHz, DMSO- $\left.d_{6}\right) 7.96$ (1 H, dd, $J$ 7.9, 0.7), 7.93-7.86 $(2 \mathrm{H}$, $\mathrm{m}), 7.72-7.61$ (1 H, m), 3.87 (3 H, s), 3.74 (1 H, dtdd, J 8.5, 7.2, 4.9, 2.3), 3.10 ( $1 \mathrm{H}, \mathrm{dd}, J 16.0,4.9$ ), 2.86 (1 H, dd, J 16.0, 8.5), 2.34 (1 H, dd, J 12.1, 7.2), 2.26 (1 H, dd, J 12.1, 7.2), $2.16(6 \mathrm{H}$, s). $\delta_{\mathrm{C}}\left(101 \mathrm{MHz}, \mathrm{DMSO}-d_{6}\right) 165.63,163.06,138.37,132.89$, 132.22, 128.44, 127.12, 127.10, 62.49, 52.08, 47.45, 45.25, 30.86. HRMS (ESI-QTOF): $m / z[\mathrm{M}+\mathrm{H}]^{+}$Calcd for $\mathrm{C}_{14} \mathrm{H}_{18} \mathrm{~N}_{2} \mathrm{O}_{3}$ 263.1390; found: $263.1412 . \delta=8.36 \mathrm{ppm}$.

7-Bromo-3-[(dimethylamino)methyl]-1,2,3,4-tetrahydroisoquinolin-1-one (15). Synthesised following general procedure B. The reaction was carried out at room temperature and the crude material was purified by flash column chromatography using a gradient of $0-10 \% \mathrm{MeOH}$ in EtOAc. The desired compound was obtained as a brown solid in 53\% yield (68 mg) from (3-bromophenyl)formamido 2,2-dimethylpropanoate (10) (0.45 mmol, $135 \mathrm{mg}, 1$ equiv.). $\delta_{\mathrm{H}}\left(400 \mathrm{MHz}, \mathrm{DMSO}-d_{6}\right) 7.91$ (1 H, d, J 2.2), 7.66 (1 H, dd, J 8.0, 2.2), 7.64 (1 H, br s), 7.30 (1 H, d, J 8.0), 3.78-3.63 (1 H, m), 2.99 (1 H, dd, J 16.0, 4.9), 2.76 (1 H, dd, $J$ 16.0, 8.5), 2.32 (1 H, dd, $J$ 12.1, 7.1), $2.25(1 \mathrm{H}$, dd, $J 12.1,7.2), 2.16$ (6 H, s). $\delta_{\mathrm{C}}\left(101 \mathrm{MHz}, \mathrm{DMSO}-d_{6}\right) 162.63$, $137.28,134.23$, 131.05, 130.13, 129.06, 119.46, 62.43, 47.41, 45.26, 30.42. HRMS (ESI-QTOF): $m / z[\mathrm{M}+\mathrm{H}]^{+}$Calcd for $\mathrm{C}_{12} \mathrm{H}_{15} \mathrm{BrN}_{2} \mathrm{O} 283.0441$; found: 283.0444. $\delta=1.06 \mathrm{ppm}$.

Methyl 3-[(dimethylamino)methyl]-1-oxo-1,2,3,4-tetrahydroisoquinoline-7-carboxylate (16). Synthesised following general procedure B. The reaction was carried out at room temperature and the crude material was purified by flash column chromatography using a gradient of $0-10 \% \mathrm{MeOH}$ in EtOAc. The desired compound was obtained as a brown solid in $56 \%$ yield (67 mg) from methyl $3-\{[(2,2$-dimethylpropanoyl)oxy $]$ carbamoyl bbenzoate (12) (0.45 mmol, $125 \mathrm{mg}, 1$ equiv.). $\delta_{\mathrm{H}}$ (400 MHz, DMSO- $d_{6}$ ) 8.41 (1 H, d, $J$ 1.9), 8.03 (1 H, dd, $J$ 7.9, 1.9), 7.65 (1 H, br s), 7.53-7.43 (1 H, m), 3.87 (3 H, s), 3.75 (1 H, dtdd, $J$ 8.5, 7.1, 4.9, 2.3), 3.10 (1 H, dd, $J$ 16.3, 4.9), 2.88 (1 H, dd, $J 16.3,8.5), 2.34$ (1 H, dd, $J$ 12.1, 7.1), 2.26 (1 H, dd, $J$ 12.1, 7.1), 2.16 (6 H, s). $\delta_{\mathrm{C}}\left(101 \mathrm{MHz}, \mathrm{DMSO}-d_{6}\right)$ 165.58, $163.31,143.34,131.90,129.31,128.43,128.22,127.46,62.49$, 51.94, 47.33, 45.27, 31.11. HRMS (ESI-QTOF): $m / z[\mathrm{M}+\mathrm{H}]^{+}$ Calcd for $\mathrm{C}_{14} \mathrm{H}_{18} \mathrm{~N}_{2} \mathrm{O}_{3}$ 263.139; found: 263.1409. $\delta=7.22 \mathrm{ppm}$.

5-[(Dimethylamino)methyl]-4H,5H,6H,7H-thieno[2,3-c] pyridin-7-one (19a). Synthesised following general procedure B. The reaction was carried out at room temperature overnight then additional catalyst was added and the reaction heated to $50{ }^{\circ} \mathrm{C}$ for 3 hours. The crude material was purified by flash column chromatography using a gradient of $0-10 \% \mathrm{MeOH}$ in EtOAc. The desired compound was obtained as a brown oil in $31 \%$ yield (30 $\mathrm{mg}$ ) from (thiophen-2-yl)formamido 2,2-dimethylpropanoate (17) (0.45 mmol, $102 \mathrm{mg}, 1$ equiv.). Note: minor isomer not isolated. Ratio estimated by LC-MS. $\delta_{\mathrm{H}}\left(400 \mathrm{MHz}, \mathrm{DMSO}-d_{6}\right) 7.76$ ( $\left.1 \mathrm{H}, \mathrm{d}, J 4.9\right), 7.16(1 \mathrm{H}, \mathrm{br} \mathrm{s})$, 7.06 (1 H, d, J 4.9), 3.80 (1 H, dtdd, J 9.2, 7.2, 5.5, 1.8), 2.95 (1 H, dd, $J$ 16.3, 5.5), 2.69 (1 H, dd, J 16.3, 9.2), 2.37 (1 H, dd, $J$ 12.0, 7.2), $2.30(1 \mathrm{H}, \mathrm{dd}, J 12.0,7.2), 2.17(6 \mathrm{H}, \mathrm{s}) . \delta_{\mathrm{C}}$ (101 MHz, DMSO- $\left.d_{6}\right)$ 161.38, 143.99, 130.97, 130.55, 127.43, 62.32, 49.35, 45.22, 27.55. HRMS (ESI-QTOF): $m / z[\mathrm{M}+\mathrm{H}]^{+}$ Calcd for $\mathrm{C}_{10} \mathrm{H}_{14} \mathrm{~N}_{2} \mathrm{OS}$ 211.0900; found: 211.0913. $\delta=$ $6.16 \mathrm{ppm}$.

5- $\{[($ tert-Butyldimethylsilyl)oxy $]$ methyl $\}-4 H, 5 H, 6 H, 7 H$-thieno [2,3-c]pyridin-7-one (20a). Synthesised following general procedure $\mathrm{B}$. The reaction was carried out at room temperature overnight then additional catalyst was added and the reaction heated to $50{ }^{\circ} \mathrm{C}$ for 3 hours. The crude material was purified by flash column chromatography using a gradient of $0-30 \%$ EtOAc in petrol. The desired compound was obtained as a colourless oil in $24 \%$ yield (65 mg) from (thiophen-2-yl)formamido 2,2-dimethylpropanoate (17) (0.9 mmol, $204 \mathrm{mg}, 1$ equiv.). $\delta_{\mathrm{H}}\left(400 \mathrm{MHz}, \mathrm{DMSO}-d_{6}\right) 7.75(1 \mathrm{H}, \mathrm{d}, J 4.9), 7.50(1 \mathrm{H}$, d, J 2.3), 7.06 (1 H, d, J 4.9), 3.72-3.64 (1 H, m), 3.62 (1 H, dd, $J$ 10.0, 4.8), 3.53 (1 H, dd, J 10.0, 7.2), 2.98 (1 H, dd, $J$ 16.6, 6.1), 2.84 (1 H, dd, J 16.6, 6.6), 0.84 ( $9 \mathrm{H}, \mathrm{s}), 0.02$ (3 H, s), $0.01(3 \mathrm{H}$, s). $\delta_{\mathrm{C}}\left(101 \mathrm{MHz}, \mathrm{DMSO}-d_{6}\right) 161.39,143.19,130.26,130.89$, 127.48, 64.05, 52.71, 25.41, 25.49, 17.83, -5.75. HRMS (ESI-QTOF): $m / z[\mathrm{M}+\mathrm{H}]^{+}$Calcd for $\mathrm{C}_{14} \mathrm{H}_{23} \mathrm{NO}_{2} \mathrm{SSi} 298.1292$; found: 298.1299. $\delta=2.35 \mathrm{ppm}$.

4- $\{[$ tert-Butyldimethylsilyl)oxy $]$ methyl $\}-4 H, 5 H, 6 H, 7 H$-thieno [2,3-c]pyridin-7-one (20b). Synthesis and purification described for 20a. compound 20b was obtained as a white solid in 55\% yield (148 mg) from (thiophen-2-yl)formamido 2,2-dimethylpropanoate (17) (0.9 mmol, $204 \mathrm{mg}, 1$ equiv.). $\delta_{\mathrm{H}}\left(400 \mathrm{MHz}, \mathrm{DMSO}-d_{6}\right) 7.76(1 \mathrm{H}, \mathrm{d}, J 5.0), 7.62(1 \mathrm{H}, \mathrm{br} \mathrm{s})$, 7.14 (1 H, dd, J 5.0, 0.4), 3.73 (1 H, dd, J 10.0, 5.4), 3.63 (1 H, dd, $J$ 10.0, 8.5), 3.52 (1 H, ddd, J 12.6, 5.4, 1.9), 3.39 (1 H, ddd, $J$ 12.7, 5.4, 3.4), 3.07 (1 H, dq, $J$ 8.5, 5.4), 0.86 (9 H, s), 0.03 $(6 \mathrm{H}, \mathrm{s}) . \delta_{\mathrm{C}}\left(101 \mathrm{MHz}, \mathrm{DMSO}-d_{6}\right) 161.35,145.25,131.57$, 130.59, 126.99, 62.56, 41.76, 37.05, 25.52, 17.83, -5.78. HRMS (ESI-QTOF): $m / z[\mathrm{M}+\mathrm{H}]^{+}$Calcd for $\mathrm{C}_{14} \mathrm{H}_{23} \mathrm{NO}_{2} \mathrm{SSi} 298.1292$; found: $298.1296 . \delta=1.34 \mathrm{ppm}$.

tert-Butyl $\quad \mathrm{N}$-(\{7-oxo-4H,5H,6H,7H-thieno[2,3-c]pyridin-5-yl\} methyl)carbamate (21a). Synthesised following general procedure B. The reaction was carried out at room temperature and the crude material was purified by flash column chromatography using a gradient of $0-30 \%$ EtOAc in petrol. The desired compound was obtained as an off-white solid in $27 \%$ yield (35 mg) from (thiophen-2-yl)formamido 2,2-dimethylpropanoate (17) $\left(0.45 \mathrm{mmol}, 102 \mathrm{mg}, 1\right.$ equiv.). $\delta_{\mathrm{H}}(400 \mathrm{MHz}$, DMSO- $\left.d_{6}\right) 7.76$ (1 H, d, J 4.9), $7.56(1 \mathrm{H}, \mathrm{br} \mathrm{s}), 7.04(1 \mathrm{H}, \mathrm{d}$, $J$ 4.9), 6.97 (1 H, t, J 5.7), 3.75-3.55 (1 H, m), 3.15-3.15 (2 H, m), 2.91 (1 H, dd, $J$ 16.4, 5.6), 2.68 (1 H, dd, $J$ 16.4, 8.8), 1.38 
(9 H, s). $\delta_{\mathrm{C}}\left(101 \mathrm{MHz}, \mathrm{DMSO}-d_{6}\right) 161.38,155.52,143.39$, 130.94, 130.08, 127.51, 77.84, 51.78, 43.13, 27.92, 26.76. HRMS (ESI-QTOF): $m / z[\mathrm{M}+\mathrm{H}]^{+}$Calcd for $\mathrm{C}_{13} \mathrm{H}_{18} \mathrm{~N}_{2} \mathrm{O}_{3} \mathrm{~S}$ 283.1111; found: $283.1114 . \delta=1.06 \mathrm{ppm}$.

tert-Butyl $\quad \mathrm{N}$-(\{7-oxo-4H,5H,6H,7H-thieno[2,3-c]pyridin-4-yl\} methyl)carbamate (21b). Synthesise and purification described for 21a. Compound 21b was obtained as a glassy yellow solid in 52\% yield (66 mg) from (thiophen-2-yl)formamido 2,2-dimethylpropanoate (17) (0.45 mmol, $102 \mathrm{mg}$, 1 equiv.). $\delta_{\mathrm{H}}$ (400 MHz, DMSO- $\left.d_{6}\right) 7.77$ (1 H, d, $J$ 5.0), 7.61 (1 H, d, J 3.0), 7.09 (1 H, d, J 5.0), 7.04 (1 H, t, J 6.8), $3.47(1 \mathrm{H}$, $\mathrm{dd}, J$ 12.5, 3.6), 3.31-3.16 (2 H, m), 3.15-2.98 (2 H, m), 1.38 $(9 \mathrm{H}, \mathrm{s}) . \delta_{\mathrm{C}}\left(101 \mathrm{MHz}, \mathrm{DMSO}-d_{6}\right) 161.50,155.71,146.37$, 131.35, 130.77, 126.54, 77.76, 42.91, 41.26, 34.83, 27.96. HRMS (ESI-QTOF): $m / z[\mathrm{M}+\mathrm{H}]^{+}$Calcd for $\mathrm{C}_{13} \mathrm{H}_{18} \mathrm{~N}_{2} \mathrm{O}_{3} \mathrm{~S}$ 283.1111; found: $283.1112 . \delta=0.35 \mathrm{ppm}$.

3-Bromo-5-[(dimethylamino)methyl]-4H,5H,6H,7H-thieno [2,3-c]pyridin-7-one (22a). Synthesised following general procedure $\mathrm{B}$. The reaction was carried out at room temperature and the crude material was purified by flash column chromatography using a gradient of $0-10 \% \mathrm{MeOH}$ in EtOAc. The desired compound was obtained as a brown solid in $30 \%$ yield (40 mg) from (4-bromothiophen-2-yl)formamido 2,2-dimethylpropanoate (18) $\left(0.45 \mathrm{mmol}, 137 \mathrm{mg}, 1\right.$ equiv.). $\delta_{\mathrm{H}}(400 \mathrm{MHz}$, DMSO- $\left.d_{6}\right) 7.98(1 \mathrm{H}, \mathrm{s}), 7.45$ (1 H, br s), 3.86 ( $1 \mathrm{H}$, dtdd, $J$ 8.8, 7.1, 5.7, 1.9), 2.85 (1 H, dd, $J 16.5,5.7), 2.63$ (1 H, dd, $J$ 16.5, 8.8), 2.41-2.28 (2 H, m), $2.17(6 \mathrm{H}, \mathrm{s}) . \delta_{\mathrm{C}}\left(101 \mathrm{MHz}, \mathrm{DMSO}-d_{6}\right)$ $160.15,142.42,131.07,128.42,109.82,62.15,49.16,45.25$, 26.97. HRMS (ESI-QTOF): $\mathrm{m} / \mathrm{z}[\mathrm{M}+\mathrm{H}]^{+}$Calcd for $\mathrm{C}_{10} \mathrm{H}_{13} \mathrm{BrN}_{2} \mathrm{OS} 289.0005$; found: $289.0009 . \delta=1.38 \mathrm{ppm}$.

3-Bromo-5-\{[(tert-Butyldimethylsilyl)oxy $]$ methyl $\}-4 H, 5 H, 6 H, 7 H^{-}$ thieno[2,3-c]pyridin-7-one (23a). Synthesised following general procedure B. The reaction was carried out at room temperature and the crude material was purified by flash column chromatography using a gradient of $0-30 \%$ EtOAc in petrol. The regioisomers were inseparable by column chromatography and were obtained as an approximately $1: 2$ mixture of $a: b$ as judged by ${ }^{1} \mathrm{H}$ NMR. The mixture was a white solid in $52 \%$ combined yield $(88 \mathrm{mg}$ ) from (4-bromothiophen-2-yl)formamido 2,2-dimethylpropanoate (18) (0.45 mmol, $137 \mathrm{mg}, 1$ equiv.). $\delta_{\mathrm{H}}\left(400 \mathrm{MHz}, \mathrm{DMSO}-d_{6}\right) 7.96(1 \mathrm{H}, \mathrm{s}), 7.77$ (1 H, d, $J$ 2.9), 3.82-3.68 (1 H, m), 3.65-3.48 (2 H, m), 2.89 (1 H, dd, J 16.8, 6.6), 2.79 (1 H, dd, $J 16.8,5.5), 0.82(9 \mathrm{H}, \mathrm{s}), 0.00(6 \mathrm{H}, \mathrm{s}) . \delta_{\mathrm{C}}$ (101 MHz, DMSO) -5.10, 17.78, 25.52, 26.15, 52.92, 64.84, 109.76, 128.97, 131.00, 141.64, 160.04. HRMS (ESI-QTOF): $\mathrm{m} / \mathrm{z}$ $[\mathrm{M}+\mathrm{H}]^{+}$Calcd for $\mathrm{C}_{14} \mathrm{H}_{22} \mathrm{BrNO}_{2} \mathrm{SSi}$ 376.0397; found: 376.0391 . $\delta=1.60 \mathrm{ppm}$.

3-Bromo-4-\{[(tert-Butyldimethylsilyl)oxy $]$ methyl $\}-4 H, 5 H, 6 H, 7 H-$ thieno[2,3-c]pyridin-7-one (23b). See the experimental information for 23a. $\delta_{\mathrm{H}}\left(400 \mathrm{MHz}, \mathrm{DMSO}-d_{6}\right) 7.99(1 \mathrm{H}, \mathrm{s}), 7.80$ (1 H, d, J 3.8), 3.60-3.48 (4 H, m), 2.95 (1 H, ddt, J 9.7, 5.3, 2.7), 0.87 (9 H, s), 0.05 (3 H, s), 0.03 (3 H, s). $\delta_{\mathrm{C}}(101 \mathrm{MHz}, \mathrm{DMSO})$ $159.87,142.60,132.68,129.19,61.34,41.32,37.17,26.26$, 17.78, -4.97, -5.06. C-Br not determined. HRMS (ESI-QTOF): $m / z[\mathrm{M}+\mathrm{H}]^{+}$Calcd for $\mathrm{C}_{14} \mathrm{H}_{22} \mathrm{BrNO}_{2} \mathrm{SSi}$ 376.0397; found: 376.0391. $\delta=1.60 \mathrm{ppm}$.
tert-Butyl $\quad N$-(\{3-bromo-7-oxo-4H,5H,6H,7H-thieno[2,3-c] pyridin-5-yl\}methyl)carbamate (24a). Synthesised following general procedure $\mathrm{B}$. The reaction was carried out at room temperature and the crude material was purified by flash column chromatography using a gradient of 0-30\% EtOAc in petrol. The desired compound was obtained as a glassy off white solid in $25 \%$ yield ( $42 \mathrm{mg}$ ) from (4-bromothiophen-2-yl) formamido 2,2-dimethylpropanoate $(0.45 \mathrm{mmol}, 137 \mathrm{mg}$, 1 equiv.). $\delta_{\mathrm{H}}(400 \mathrm{MHz}$, chloroform- $d$ ) 7.48 (1 H, s), 6.22 ( $1 \mathrm{H}$, br s), 4.91 (1 H, br s), 3.99 (1 H, br s), 3.47-3.34 (1 H, m), 3.28 (1 H, dt, J 14.2, 7.0), 2.90 (1 H, dd, $J$ 16.5, 5.6), 2.67 (1 H, dd, $J$ 16.5, 10.0), 1.46 (9 H, s). $\delta_{\mathrm{C}}(101 \mathrm{MHz}$, $\left.\mathrm{CDCl}_{3}\right)$ 128.50, 52.92, 44.45, 27.48, 28.31. 162.13, 142.78, 131.18, 110.72. Sidechain NCO not determined. OCG(Me $)_{3}$ under chloroform resonances. HRMS (ESI-QTOF): $m / z[\overline{\mathrm{M}}+\mathrm{H}]^{+}$ Calcd for $\mathrm{C}_{13} \mathrm{H}_{17} \mathrm{BrN}_{2} \mathrm{O}_{3} \mathrm{~S}$ 361.0216; found: 361.0214. $\delta=$ $0.55 \mathrm{ppm}$.

tert-Butyl $\quad N$-(\{3-bromo-7-oxo-4H,5H,6H,7H-thieno[2,3-c] pyridin-4-yl\}methyl)carbamate (24b). Synthesis and purification described for 24a. Compound $\mathbf{2 4 b}$ was obtained as a glassy off white solid in $29 \%$ yield (48 mg) from (4-bromothiophen-2-yl)formamido 2,2-dimethylpropanoate (18) (0.45 mmol, $137 \mathrm{mg}, 1$ equiv.). $\delta_{\mathrm{H}}$ (400 MHz, DMSO- $\left.d_{6}\right) 7.96(1 \mathrm{H}, \mathrm{s}), 7.75$ (1 H, d, J 4.5), 7.08 (1 H, br s), 3.55 (1 H, dd, J 13.0, 3.4), 3.41 (1 H, dd, $J$ 13.0, 4.7), 3.08-2.92 (3 H, m), $1.38(9 \mathrm{H}, \mathrm{s}) . \delta_{\mathrm{C}}$ (101 MHz, DMSO) 160.14, 155.56, 144.37, 132.28, 128.60, 109.72, 77.71, 41.82, 34.06, 30.63, 28.21. HRMS (ESI-QTOF): $m / z[\mathrm{M}+\mathrm{H}]^{+}$Calcd for $\mathrm{C}_{13} \mathrm{H}_{17} \mathrm{BrN}_{2} \mathrm{O}_{3} \mathrm{~S}$ 361.0216; found: 361.0211. $\delta=1.38 \mathrm{ppm}$.

6- $\{[($ tert-Butyldimethylsilyl)oxy $]$ methyl $\}-2-c h l o r o-4 H, 5 H, 6 H, 7 H-$ $[1,3]$ thiazolo[5,4-c]pyridin-4-one (26a). Synthesised following general procedure $\mathrm{B}$. The reaction was carried out at room temperature and the crude material was purified by flash column chromatography using a gradient of $0-30 \%$ EtOAc in petrol. The regioisomers were inseparable by column chromatography and were obtained as an approximately 1:4 mixture of $\mathrm{a}: \mathrm{b}$ as judged by ${ }^{1} \mathrm{H}$ NMR. The mixture was a white solid $36 \%$ yield (54 mg) from (2-chloro-1,3-thiazol-5yl)formamido 2,2-dimethylpropanoate (25) (0.45 mmol, $118 \mathrm{mg}, 1$ equiv.). $\delta_{\mathrm{H}}\left(400 \mathrm{MHz}, \mathrm{DMSO}-d_{6}\right) 7.92(1 \mathrm{H}, \mathrm{d}$, J 2.8), 3.81-3.71 (1 H, m), 3.67-3.58 (2 H, m), 3.13 (1 H, dd, $J$ 17.1, 7.1), 2.95 (1 H, dd, $J$ 17.1, 5.4), 0.81 (9 H, s), 0.00 (6 $\mathrm{H}, \mathrm{s})$.

7-\{[(tert-Butyldimethylsilyl)oxy]methyl\}-2-chloro- $4 \mathrm{H}, 5 \mathrm{H}, 6 \mathrm{H}, 7 \mathrm{H}$ $[1,3]$ thiazolo[5,4-c]pyridin-4-one (26b). Major regioisomer. $\delta_{\mathrm{H}}\left(400 \mathrm{MHz}, \mathrm{DMSO}-d_{6}\right) 7.97$ (1 H, br s), 3.85 (1 H, dd, $J$ 10.2, 4.4), 3.81-3.74 (1 H, m), 3.66-3.55 (1 H, m), 3.47 (1 H, ddd, J 12.9, 5.9, 3.2), 3.21 (1 H, dtd, J 7.9, 5.9, 4.4), 0.84 (9 H, s), 0.03 (3 H, s), 0.01 (3 H, s).

2-Chloro-6-(hydroxymethyl)-4H,5H,6H,7H-[1,3]thiazolo[5,4-c] pyridin-4-one (27a). TBAF ( $0.243 \mathrm{ml}, 0.243 \mathrm{mmol}, 1.5 \mathrm{eq}$.) was added to the regioisomeric mixture of silyl ethers $26 \mathbf{a}$ and $\mathbf{b}$ in THF. The reaction was stirred at room temperature for $1 \mathrm{~h}$ then concentrated and purified by preparative HPLC to give the separated regioisomers. Regioisomer 27a was obtained as a white solid $1.5 \mathrm{mg}, 4 \%$ yield. $\delta_{\mathrm{H}}\left(400 \mathrm{MHz}, \mathrm{DMSO}-d_{6}\right) 7.89$ 
(1 H, br s), 4.98 (1 H, m), 3.72 (1 H, dtdd, J 7.5, 6.5, 5.2, 2.4), 3.52-3.37 (2 H, m), 3.06 (1 H, dd, $J$ 17.1, 6.5), 2.94 (1 H, dd, $J$ 17.1, 7.5). $\delta_{\mathrm{C}}\left(101 \mathrm{MHz}, \mathrm{DMSO}-d_{6}\right) 159.83,157.00,154.06$, 127.25, 62.66, 52.56, 26.68. HRMS (ESI-QTOF): $m / z[\mathrm{M}+\mathrm{H}]^{+}$ Calcd for $\mathrm{C}_{7} \mathrm{H}_{7} \mathrm{ClN}_{2} \mathrm{O}_{2} \mathrm{~S}$ 218.9990; found: 218.999. $\delta=$ $0.00 \mathrm{ppm}$.

2-Chloro-7-(hydroxymethyl)-4H,5H,6H,7H-[1,3]thiazolo[5,4-c] pyridin-4-one (27b). This regiosiomer was obtained as a white solid $15 \mathrm{mg}, 42 \%$ yield. $\delta_{\mathrm{H}}\left(400 \mathrm{MHz}, \mathrm{DMSO}-d_{6}\right) 7.95(1 \mathrm{H}$, br s), 4.97 (1 H, t, J 4.6), 3.69 (1 H, dd, J 9.4, 5.2), 3.64-3.45 (3 H, $\mathrm{m}), 3.21-3.07(1 \mathrm{H}, \mathrm{m}) . \delta_{\mathrm{C}}\left(101 \mathrm{MHz}, \mathrm{DMSO}-d_{6}\right) 159.82,158.72$, 154.03, 128.63, 60.01, 41.47, 38.34. HRMS (ESI-QTOF): $\mathrm{m} / \mathrm{z}$ $[\mathrm{M}+\mathrm{H}]^{+}$Calcd for $\mathrm{C}_{7} \mathrm{H}_{7} \mathrm{ClN}_{2} \mathrm{O}_{2} \mathrm{~S} 218.9990$; found 218.9992. $\delta=$ $0.91 \mathrm{ppm}$.

6- $\{[($ tert-Butyldimethylsilyl)oxy $]$ methyl $\}-4 H, 5 H, 6 H, 7 H-[1,3]$ thiazolo[5,4-c]pyridin-4-one (29a). Synthesised following general procedure $B$. The reaction was carried out at room temperature and the crude material was purified by flash column chromatography using a gradient of $0-30 \%$ EtOAc in petrol. The regioisomers were not separable by column chromatography and were obtained as an approximately $1: 2$ mixture of a : b as judged by ${ }^{1} \mathrm{H}$ NMR. The mixture was a white solid in $16 \%$ yield (22 mg) from (1,3-thiazol-5-yl)formamido 2,2-dimethylpropanoate (0.45 mmol, $102 \mathrm{mg}, 1$ equiv.). $\delta_{\mathrm{H}}\left(400 \mathrm{MHz}, \mathrm{DMSO}-d_{6}\right) 9.22(1 \mathrm{H}, \mathrm{s}), 7.77$ (1 H, d, $J$ 2.7), 3.81-3.72 (1 H, m), 3.67-3.53 (2 H, m), 3.17 (1 H, dd, J 16.9, 6.8), 3.03 (1 H, dd, $J$ 16.9, 5.8), 0.81 (9 H, s), -0.00 (6 H, s). $\delta_{\mathrm{C}}(101 \mathrm{MHz}, \mathrm{DMSO}) 158.19,157.76,124.64,51.95,64.49$, 26.57, 25.47, 17.78, -5.76. $\mathrm{C}=\mathrm{O}$ not determined. HRMS (ESI-QTOF): $m / z[\mathrm{M}+\mathrm{H}]^{+}$Calcd for $\mathrm{C}_{13} \mathrm{H}_{22} \mathrm{~N}_{2} \mathrm{O}_{2} \mathrm{SSi} 299.1244$; found 299.1247. $\delta=1.02 \mathrm{ppm}$.

$7-\{[($ tert-Butyldimethylsilyl)oxy $]$ methyl $\}-4 H, 5 H, 6 H, 7 H-[1,3]$ thiazolo[5,4-c]pyridin-4-one (29b). Procedure described for 29a. $\delta_{\mathrm{H}}\left(400 \mathrm{MHz}, \mathrm{DMSO}-d_{6}\right) 9.25(1 \mathrm{H}, \mathrm{s}), 7.85$ (1 H, br s), 3.90 (1 H, dd, J 10.1, 4.3), 3.73 (1 H, dd, J 10.1, 8.7), 3.64-3.57 (1 H, m), 3.49 (1 H, ddd, J 12.8, 5.6, 3.2), 3.28-3.22 (1 H, m), 0.85 (9 $\mathrm{H}, \mathrm{s}), 0.04(3 \mathrm{H}, \mathrm{s}), 0.02(3 \mathrm{H}, \mathrm{s}) . \delta_{\mathrm{C}}\left(101 \mathrm{MHz}, \mathrm{DMSO}-d_{6}\right)$ $160.94,159.47,157.80,126.41,61.84,41.57,38.02$, 25.47, $17.81,-5.76$.

7-Bromo-3-[(dimethylamino)methyl]-1,2,3,4-tetrahydro-2,6naphthyridin-1-one (31). Synthesised following general procedure B. The reaction mixture was heated to $65^{\circ} \mathrm{C}$ for 4 hours then worked up and the crude material was purified by flash column chromatography using a gradient of $0-30 \%$ EtOAc in petrol to give a mixture of regioisomers. The major component was isolated by preparative HPLC to give the structure indicated as a white solid in $8 \%$ yield $(10 \mathrm{mg}$ ) from (2-bromopyridin-4-yl)formamido 2,2-dimethylpropanoate (0.45 mmol, $135 \mathrm{mg}, 1$ equiv.). $\delta_{\mathrm{H}}\left(400 \mathrm{MHz}\right.$, DMSO- $\left.d_{6}\right) 8.46$ (1 H, d, J 0.7), 8.12-7.99 (1 H, m), 7.81 (1 H, d, J 0.7), 3.83-3.70 (1 H, m), 3.04 (1 H, dd, J 16.1, 5.0), 2.79 (1 H, dd, J 16.1, 8.1), 2.32 ( $1 \mathrm{H}, \mathrm{dd}, J 12.2,6.8), 2.26$ (1 H, dd, J 12.2, 7.5), 2.16 (6 H, s). $\delta_{\mathrm{C}}(101 \mathrm{MHz}, \mathrm{DMSO}) 161.16,150.36,139.56,138.67,132.11$, 124.10, 62.26, 47.56, 45.32, 27.32. HRMS (ESI-QTOF): $\mathrm{m} / \mathrm{z}$ $[\mathrm{M}+\mathrm{H}]^{+}$Calcd for $\mathrm{C}_{11} \mathrm{H}_{14} \mathrm{BrN}_{3} \mathrm{O} 284.0393$; found 284.0394. $\delta=$ $0.23 \mathrm{ppm}$.

\section{Acknowledgements}

The authors warmly thank our Astex colleagues, Stuart Whibley and Nicola Wilsher for providing the HRMS data.

\section{Notes and references}

1 (a) D. Erlanson, Introduction to Fragment-Based Drug Discovery, in Fragment-Based Drug Discovery and X-Ray Crystallography, ed. T. G. Davies and M. Hyvönen, Springer, Berlin Heidelberg, 2012, vol. 317, pp. 1-32; (b) R. E. Hubbard and J. B. Murray, Chapter twenty - Experiences in FragmentBased Lead Discovery, in Methods in Enzymology, ed. C. K. Lawrence, Academic Press, 2011, vol. 493, pp. 509-531; (c) T. V. Magee, Progress in discovery of smallmolecule modulators of protein-protein interactions via fragment screening, Bioorg. Med. Chem. Lett., 2015, 25(12), 2461-2468; (d) C. W. Murray and D. C. Rees, The rise of fragment-based drug discovery, Nat. Chem., 2009, 1(3), 187192; (e) E. R. Zartler, Fragonomics: The -Omics with Real Impact, ACS Med. Chem. Lett., 2014, 5(9), 952-953; (f) J. P. Burke, Z. Bian, S. Shaw, B. Zhao, C. M. Goodwin, J. Belmar, C. F. Browning, D. Vigil, A. Friberg, D. V. Camper, O. W. Rossanese, T. Lee, E. T. Olejniczak and S. W. Fesik, Discovery of Tricyclic Indoles That Potently Inhibit Mcl-1 Using Fragment-Based Methods and Structure-Based Design, J. Med. Chem., 2015, 58(9), 3794-3805.

2 M. Baker, Fragment-based lead discovery grows up, Nat. Rev. Drug Discovery, 2013, 12(1), 5-7.

3 G. Bollag, J. Tsai, J. Zhang, C. Zhang, P. Ibrahim, K. Nolop and P. Hirth, Vemurafenib: the first drug approved for BRAF-mutant cancer, Nat. Rev. Drug Discovery, 2012, 11(11), 873-886.

4 C. W. Murray and D. C. Rees, Opportunity Knocks: Organic Chemistry for Fragment-Based Drug Discovery (FBDD), Angew. Chem., Int. Ed., 2015, DOI: 10.1002/anie.201506783, published on line Nov 3, 2015.

5 (a) M. Congreve, R. Carr, C. Murray and H. Jhoti, A 'Rule of Three' for fragment-based lead discovery?, Drug Discovery Today, 2003, 8(19), 876-877; (b) H. Jhoti, G. Williams, D. C. Rees and C. W. Murray, The 'rule of three' for fragment-based drug discovery: where are we now?, Nat. Rev. Drug Discovery, 2013, 12(8), 644-644.

6 (a) N. Baurin, F. Aboul-Ela, X. Barril, B. Davis, M. Drysdale, B. Dymock, H. Finch, C. Fromont, C. Richardson, H. Simmonite and R. E. Hubbard, Design and Characterization of Libraries of Molecular Fragments for Use in NMR Screening against Protein Targets, J. Chem. Inf. Comput. Sci., 2004, 44(6), 2157-2166; (b) N. Blomberg, D. Cosgrove, P. Kenny and K. Kolmodin, Design of compound libraries for fragment screening, J. Comput. Aided Mol. Des., 2009, 23 (8), 513-525; (c) J. Fejzo, C. A. Lepre, J. W. Peng, G. W. Bemis, Ajay, M. A. Murcko and J. M. Moore, The SHAPES strategy: an NMR-based approach for lead generation in drug discovery, Chem. Biol., 1999, 6(10), 755-769; 
(d) W. Lau, J. Withka, D. Hepworth, T. Magee, Y. Du, G. Bakken, M. Miller, Z. Hendsch, V. Thanabal, S. Kolodziej, L. Xing, Q. Hu, L. Narasimhan, R. Love, M. Charlton, S. Hughes, W. van Hoorn and J. Mills, Design of a multi-purpose fragment screening library using molecular complexity and orthogonal diversity metrics, J. Comput. Aided Mol. Des., 2011, 25(7), 621-636; (e) A. Schuffenhauer, S. Ruedisser, A. Marzinzik, W. Jahnke, P. Selzer and E. Jacoby, Library Design for Fragment Based Screening, Curr. Top. Med. Chem., 2005, 5(8), 751-762; (f) A. D. Morley, A. Pugliese, K. Birchall, J. Bower, P. Brennan, N. Brown, T. Chapman, M. Drysdale, I. H. Gilbert, S. Hoelder, A. Jordan, S. V. Ley, A. Merritt, D. Miller, M. E. Swarbrick and P. G. Wyatt, Fragment-based hit identification: thinking in 3D, Drug Discovery Today, 2013, 18(23-24), 1221-1227; ( $g$ ) http://www.maggichurchouseevents.co.uk/bmcs/Downloads/Fragments\%20-\%20Mon\% 201115\%20Brennan\%20Paul.pdf.

7 B. J. Davis and D. A. Erlanson, Learning from our mistakes: the 'unknown knowns' in fragment screening, Bioorg. Med. Chem. Lett., 2013, 23(10), 2844-2852.

8 (a) M. M. Hann, A. R. Leach and G. Harper, Molecular Complexity and Its Impact on the Probability of Finding Leads for Drug Discovery, J. Chem. Inf. Comput. Sci., 2001, 41(3), 856-864; (b) A. R. Leach and M. M. Hann, Molecular complexity and fragment-based drug discovery: ten years on, Curr. Opin. Chem. Biol., 2011, 15(4), 489-496.

9 N. Guimond, S. I. Gorelsky and K. Fagnou, Rhodium(III)Catalyzed Heterocycle Synthesis Using an Internal Oxidant: Improved Reactivity and Mechanistic Studies, J. Am. Chem. Soc., 2011, 133(16), 6449-6457.

10 (a) J. R. Huckins, E. A. Bercot, O. R. Thiel, T.-L. Hwang and M. M. Bio, Rh(III)-Catalyzed C-H Activation and Double Directing Group Strategy for the Regioselective Synthesis of Naphthyridinones, J. Am. Chem. Soc., 2013, 135(39), 1449214495; (b) T. K. Hyster, D. M. Dalton and T. Rovis, Ligand design for $\mathrm{Rh}(\mathrm{III})$-catalyzed $\mathrm{C}-\mathrm{H}$ activation: an unsymmetrical cyclopentadienyl group enables a regioselective synthesis of dihydroisoquinolones, Chem. Sci., 2015, 6(1), 254258; (c) S. Rakshit, C. Grohmann, T. Besset and F. Glorius, $\mathrm{Rh}(\mathrm{III})$-Catalyzed Directed $\mathrm{C}-\mathrm{H}$ Olefination Using an Oxidizing Directing Group: Mild, Efficient, and Versatile, J. Am. Chem. Soc., 2011, 133(8), 2350-2353; (d) T. K. Hyster, L. Knörr, T. R. Ward and T. Rovis, Biotinylated Rh(III)
Complexes in Engineered Streptavidin for Accelerated Asymmetric C-H Activation, Science, 2012, 338(6106), 500503; (e) B. Ye and N. Cramer, Chiral cyclopentadienyl ligands as stereocontrolling element in asymmetric $\mathrm{C}-\mathrm{H}$ functionalization, Science, 2012, 338(6106), 504-506.

11 N. J. Webb, S. P. Marsden and S. A. Raw, Rhodium(III)Catalyzed C-H Activation/Annulation with Vinyl Esters as an Acetylene Equivalent, Org. Lett., 2014, 16(18), 47184721.

12 B. Ye and N. Cramer, Asymmetric Synthesis of Isoindolones by Chiral Cyclopentadienyl-Rhodium(III)-Catalyzed $\mathrm{C}-\mathrm{H}$ Functionalizations, Angew. Chem., Int. Ed., 2014, 53(30), 7896-7899.

13 D. Dou, P. Viwanathan, Y. Li, G. He, K. R. Alliston, G. H. Lushington, J. D. Brown-Clay, R. Padmanabhan and W. C. Groutas, Design, Synthesis, and In Vitro Evaluation of Potential West Nile Virus Protease Inhibitors Based on the 1-Oxo-1,2,3,4-tetrahydroisoquinoline and 1-Oxo-1,2dihydroisoquinoline Scaffolds, J. Comb. Chem., 2010, 12(6), 836-843.

14 S. Wu, R. Zeng, C. Fu, Y. Yu, X. Zhang and S. Ma, Rhodium-catalyzed $\mathrm{C}-\mathrm{H}$ functionalization-based approach to eight-membered lactams, Chem. Sci., 2015, 6(4), 22752285.

15 N. Guimond, C. Gouliaras and K. Fagnou, Rhodium(III)Catalyzed Isoquinolone Synthesis: The $\mathrm{N}-\mathrm{O}$ Bond as a Handle for C-N Bond Formation and Catalyst Turnover, J. Am. Chem. Soc., 2010, 132(20), 6908-6909.

16 M. Presset, D. Oehlrich, F. Rombouts and G. A. Molander, Complementary Regioselectivity in Rh(III)-Catalyzed Insertions of Potassium Vinyltrifluoroborate via C-H Activation: Preparation and Use of 4-Trifluoroboratotetrahydroisoquinolones, Org. Lett., 2013, 15(7), 1528-1531.

17 A. Nadin, C. Hattotuwagama and I. Churcher, LeadOriented Synthesis: A New Opportunity for Synthetic Chemistry, Angew. Chem., Int. Ed., 2012, 51(5), 1114-1122.

18 Z. Zhang, Y. Yu and L. S. Liebeskind, N-Amidation by Copper-Mediated Cross-Coupling of Organostannanes or Boronic Acids with O-Acetyl Hydroxamic Acids, Org. Lett., 2008, 10(14), 3005-3008.

19 R. D. Farrant, J. C. Hollerton, S. M. Lynn, S. Provera, P. J. Sidebottom and R. J. Upton, NMR quantification using an artificial signal, Magn. Reson. Chem., 2010, 48(10), 753762. 